\title{
Searching for tūpuna : Whakapapa researchers and public libraries
}

by

\section{Moata Nicola Tamaira}

Submitted to the School of Information Management, Victoria University of Wellington in partial fulfilment of the requirements for the degree of Master of Library and Information Studies

\section{October 2007}




\section{Acknowledgements}

I would like to thank my supervisor Alastair Smith for his calm and considered advice that has helped me come to the end of what has been a very long and drawn out process. In addition thanks goes to my fellow MLIS students whose advice and support has been similarly invaluable. Thanks also to Heidi Kuglin upon whose research much of this study is based.

I would like to acknowledge the contribution made by the membership of the Māori Interest Group of the New Zealand Society of Genealogists, in particular "Te Reo" editor Bruce Mathers and MIG secretary Brenda Joyce. Your enthusiasm and interest made me determined to soldier on. Also, to the members of Te Rōpū Whakahau who helped by asking questions, or filling out pilot surveys, many thanks.

To the managers who kindly gave their permission for me to distribute my questionnaire in their institutions, Bernie Hawke, Joanne Horner, Carolyn Robertson, Whina Te Whiu, and in particular Raewyn Paewai for her seemingly endless enthusiasm. I could not have undertaken this project without your support or that of your staff, particularly Ann Reweti, and Jean Strachan.

To my colleagues at Christchurch City Libraries for their willingness to accommodate my study needs, and for their unending patience and support, I am fortunate to work alongside you in this crazy library business. And finally, to my friends and family, I couldn't have done it without you. Arohanui ki a koutou katoa.

Moata Tamaira

2007 


\section{Table of Contents}

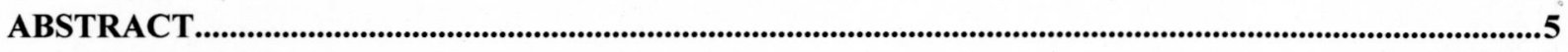

1. INTRODUCTION

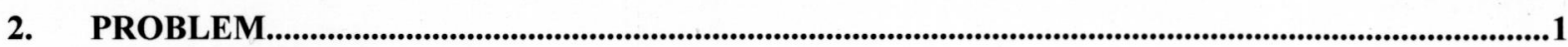

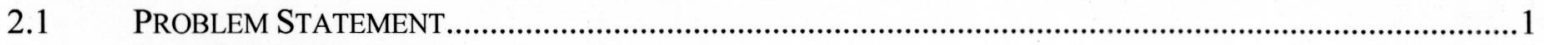

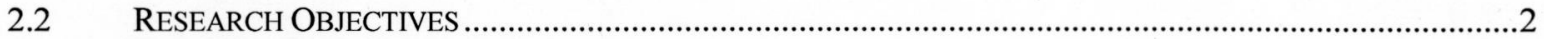

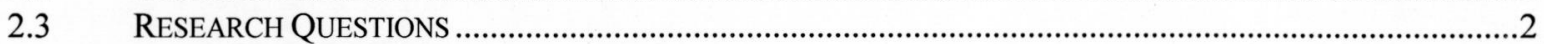

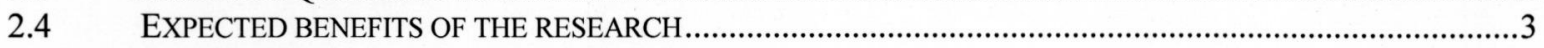

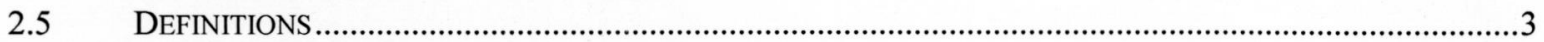

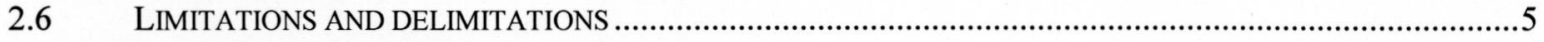

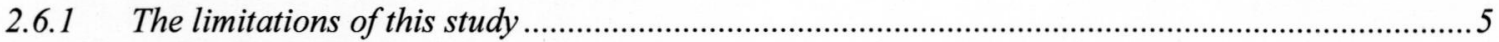

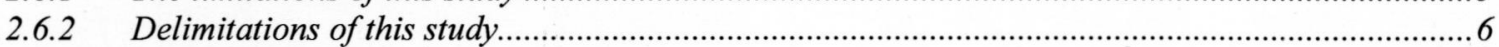

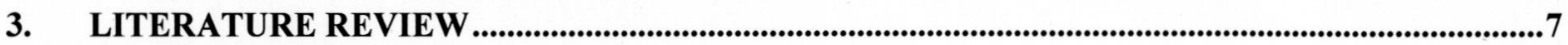

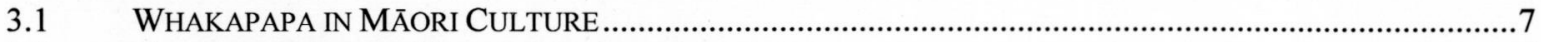

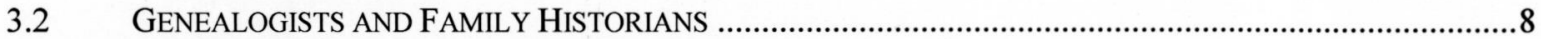

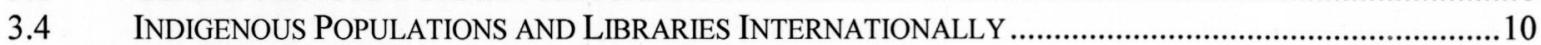

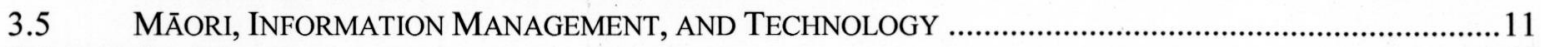

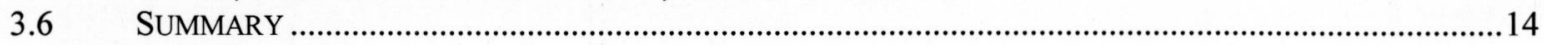

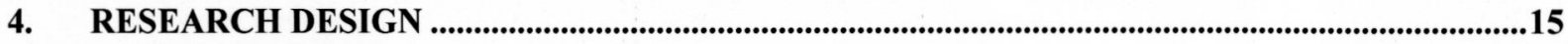

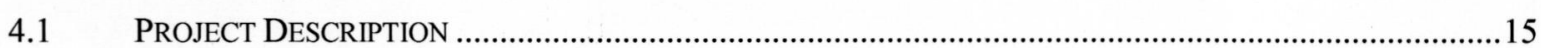

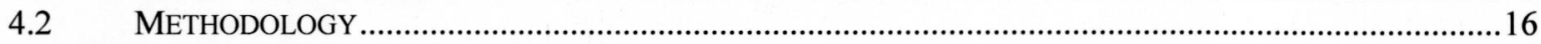

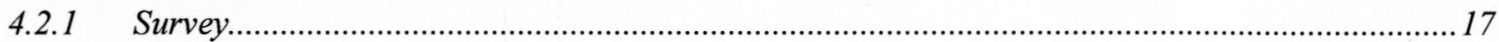

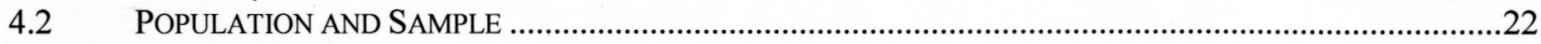

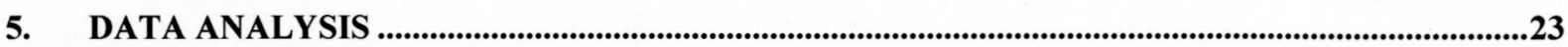

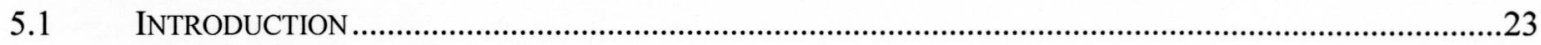

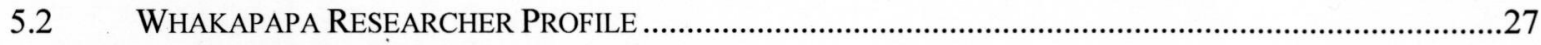

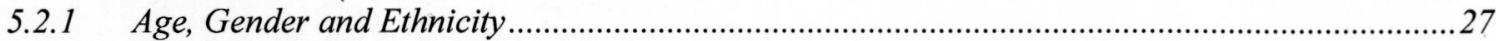

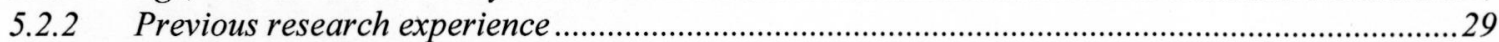

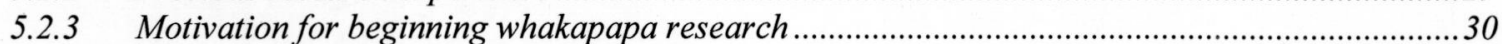

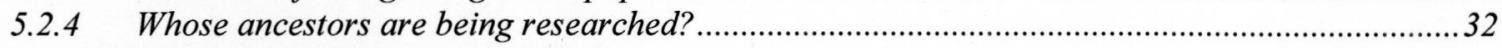

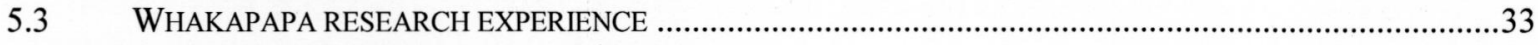

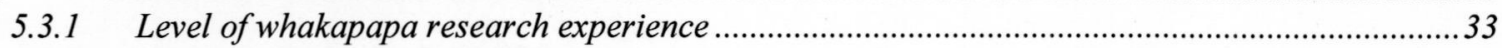

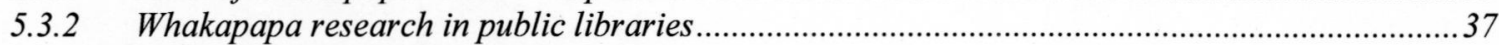

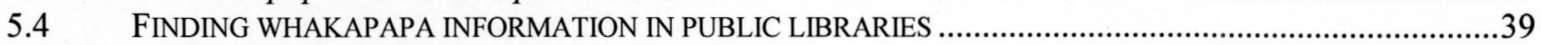

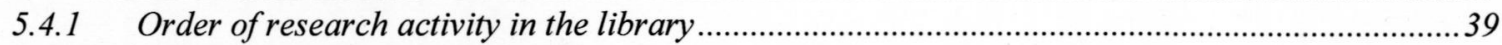

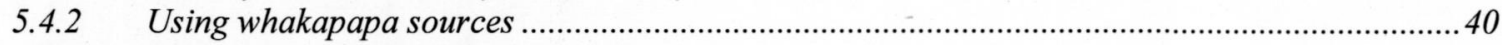

5.4.3 Using sources of information effectively................................................................................. 43

5.4.4 Librarian produced materials used by whakapapa researchers ............................................... 45

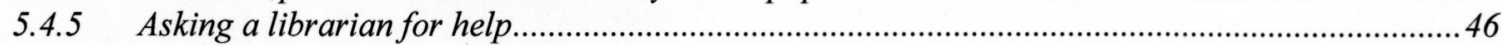

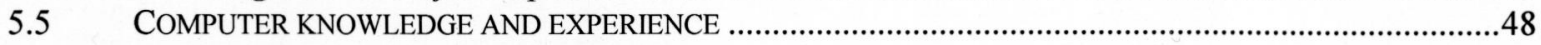

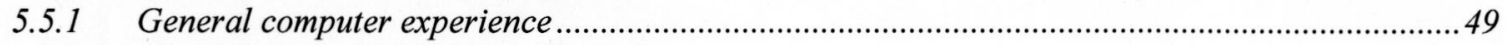

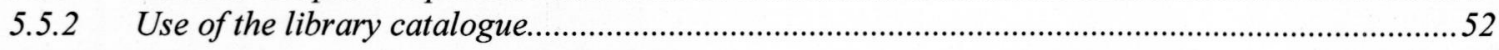

6. CONCLUSIONS AND RECOMMENDATIONS ...........................................................................56

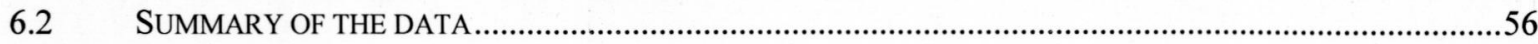

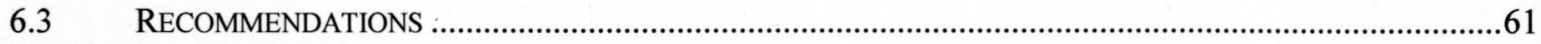

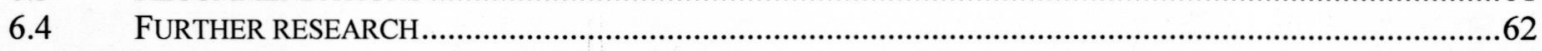

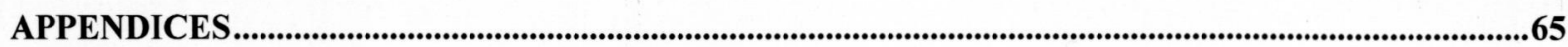

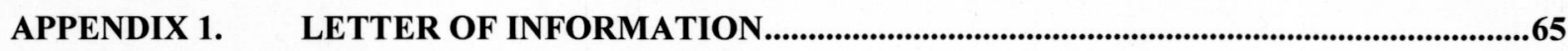

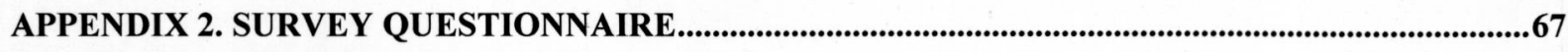

APPENDIX 3. AGGREGATE DATA FOR QUESTION 10 ....................................................................73 
BIBLIOGRAPHY 


\section{Abstract}

Genealogists are frequent users of public libraries and other institutions that hold historical material. In recent years research has investigated the information needs of this group, the motivating factors behind their involvement in this hobby. Attempts have also been made to compile a "profile" of the typical genealogist. Research in this area has been done in response to the long association genealogists have had with libraries and in acknowledgement of the growing popularity of this pastime.

Similar research methodologies as have been used overseas have been utilised in this piece of research with respect to genealogists in New Zealand, specifically those researching the family history of Māori, the indigenous people of that country. In traditional Māori culture great significance is placed on family history or whakapapa. This study aimed to investigate to what degree the use of public libraries by genealogists researching this cultural group reflected findings of library use and information seeking behaviour of genealogists in other cultural environments. Whakapapa research may be undertaken by genealogists who do not have Māori ancestors, or tūpuna, themselves and these library users still fall within the scope of this study.

Data was collected by using printed questionnaires distributed to public libraries in New Zealand, as well as a printable version of the questionnaire that was made available online .

Keywords: genealogists, family historians, indigenous, Māori, libraries, whakapapa 


\section{Introduction}

This research project was undertaken to investigate the use of public libraries in New Zealand by researchers into Māori family history, or whakapapa. Though genealogists or family historians have been the subject of research in other countries, comparatively little investigation has dealt with genealogists and their use of public library resources in New Zealand. As a result, very little is known of how whakapapa researchers use these resources. This piece of research surveyed whakapapa researchers throughout the country with the aim of determining if the conclusions relating to genealogists in general, would apply in this more specific cultural setting. The research focused on whakapapa researchers' use of public library resources with the aim to better inform these institutions of the needs of this group of users.

\section{Problem}

\subsection{Problem Statement}

There exists a body of literature (see 4. Literature Review) about genealogists and their information needs, however until now there has been no research that addresses the specific needs of researchers of Māori genealogy. Though some researchers in this area may be non-Māori it is reasonable to assume that most will have Māori ancestry and that certain cultural factors such as those discussed later may have some bearing. Projections from Statistics New Zealand (2005) state that the number of New Zealanders with Māori forebears will increase significantly in the next 15 years $^{1}$ therefore increasing the significance of this user group to public library services. In addition there are specific factors at work in a Māori cultural setting such

\footnotetext{
${ }^{1}$ Estimates from Statistics New Zealand (2005) (pg. 142) anticipate Māori rising to $29 \%$ of the population by 2021.
} 
as the broader role that whakapapa plays and issues with technology that have not been incorporated into previous research. This gap in current research makes it difficult for those providing public library services to this body of users to accurately assess or anticipate the information needs of whakapapa researchers, a group that will likely grow in the future.

\subsection{Research Objectives}

This research project aims to -

- find out how whakapapa researchers use public library services.

- compare the results relating to whakapapa researchers with those found in literature on genealogists in general to illuminate any differences between these groups of library users.

- use the data collected and resulting analysis to create a picture of what steps public libraries might take to enhance their services to this user group.

\subsection{Research Questions}

In support of the objectives stated above the following questions will be addressed in the course of the study.

- What is the profile of the whakapapa researcher, in terms of age, gender, ethnicity, level of research experience, and motivations?

- What key sources do whakapapa researchers seek out and use in public libraries?

- What resources do whakapapa researchers use in public libraries?

- What search strategies do whakapapa researchers employ?

- Are whakapapa researchers confident users of information technology? 
To a large degree these research questions mirror those used by Kuglin (2004) in order to compile similar data sets that lend themselves well to comparison in the analysis phase of the study.

\subsection{Expected benefits of the research}

The information seeking behaviours, and needs of whakapapa researchers have not so far been investigated in LIS research. As both the popularity of genealogy and the proportion of Māori represented in the population increase it will be necessary for librarians to have information on how to best meet the needs of this group of users. If library professionals make assumptions about what whakapapa researchers require in public libraries on the basis of research done in North America they run the risk of making poor decisions and potentially alienating this user group. Māori have often had issues around using libraries in the past and this has been discussed by those in the library field such as Szekely (1997). The expectation in conducting research that addresses Māori cultural factors in family history research is that it will result in a more informed public library service. The data gathered in this study will inform the final recommendations made there. These recommendations will be practical, achieveable steps that public libraries can take that will enhance the service and library experience of whakapapa researchers in New Zealand.

\subsection{Definitions}

The following terms will be used throughout this research proposal -

Genealogy is the study of lineage of one or more families, often with the view to creating a family tree or pedigree chart. 
Family history relates to, but is not the same as, genealogy. Where genealogy is concerned strictly with lineage, family history allows for the inclusion of broader contextual information about families and individuals.

Information seeking behaviours refers to the strategies that researchers employ in finding the sources that will further their research. This may include the use of a range of resources.

Public libraries refers to those libraries that are funded by local government rather than libraries that are accessible to the general public.

Resource is an item that has been produced by the library or librarian to help researchers find specific sources within the library collection. Printed or website based guides, archival finding aides, and computer catalogues are all examples of resources.

"Source is a published or unpublished item purchased or acquired by a library as a part of its colleciton and is catalogued" Kuglin (2004). Examples of whakapapa sources include Māori Land Court records, Birth, death, and marriage records, and published genealogies of Māori families.

Search strategies are those patterns of information seeking behaviour that are favoured by the researchers in question. Search strategies will relate to the use of resources within the public library setting such as use of computer catalogues etc. 
Whakapapa is a Māori word meaning family history or genealogy, although it can also apply in contexts other than genealogy.

Whakapapa researchers are researchers, either professional or amateur, who study and investigate the family history and lineage of Māori New Zealanders either regarding their own ancestry or someone elses.

\subsection{Limitations and delimitations}

\subsubsection{The limitations of this study}

Due to the Māori population of New Zealand being a minority one there it was considered that there might be some difficulty in gaining a large enough data sample. It was hoped that by distributing the survey in the main centres that a larger number of researchers would come into contact with the surveys therefore increasing the likelihood of an acceptable number of completed surveys. In addition those researchers not living in the urban centres that have distribution points could still have access to the printed survey online via the Māori Interest Group, New Zealand Society of Genealogists (MIG-NZSG) website.

There was the possibility of there being some self-selection bias. Possibly more experienced whakapapa researchers would be more likely to complete the survey as a result of their greater commitment and interest in the subject. Again the provision of an online distribution point for the survey could have made it more likely for younger researchers to participate. The use of an online survey by Drake (2001) had this effect and on the whole younger researchers will have been involved in their 
research for less time so responses from less experienced researchers might be more likely as a result.

As several distribution points for the survey were chosen from around the country, the researcher was unable to attend to these personally. This was potentially problematic in terms of consistency of promotion around the various sites. Also communication between the researcher and distribution points was very important in order to keep to prescribed timetables.

\subsubsection{Delimitations of this study}

This research project is concerned with the use of public libraries only though whakapapa researchers may well use many different institutions such as museum libraries and archives, as well as repositories of tribal information. Modern public libraries supply a wide range of sources for whakapapa researchers including access to online sources.

This research project focuses on whakapapa researchers in New Zealand. The bulk of information sources for Māori family history will be located in New Zealand though information may also be available in institutions overseas. In addition significant numbers of Māori, and by extension whakapapa researchers, live in other countries, particularly Australia where almost 73,000 people of Māori descent live². This project is not concerned with ex-patriate whakapapa researchers and looks specifically at those using New Zealand public libraries.

\footnotetext{
${ }^{2}$ from Australian Bureau of Statistics (2006)
} 


\section{Literature Review}

In surveying the literature produced in the LIS (Library and Information Science) field on the topic of genealogy researchers it becomes clear that most of the research focuses on populations other than the one that is the subject for this study, Māori. Where Māori have been the subject of study there has generally been a different focus for the research. Research on family historians and genealogists (terms that are generally used interchangeably in the literature) have not so far focused on Māori family history research in public libraries.

\subsection{Whakapapa in Mãori Culture}

Whakapapa is often translated as Māori family history or genealogy and while this is probably the easiest definition it is not necessarily the most complete one. Whakapapa is fully discussed by Hemara (2005) who argues that one of the functions of whakapapa is to "rationalise existence and explain the origins of the universe" (p. 1). Whakapapa acts as a taxonomy showing the interrelation of Gods and natural phenomenon as well as people. Similarly Royal (1993) describes whakapapa research as "a spiritual journey"(p. 10) however this is in the context, not of a research study, but of a guide for those embarking on whakapapa research.

Such is the lack of peer-reviewed research in this area however that Royal's comments are as authoritative as any. These concepts are not generally expressed as an aspect of family history research in other cultural contexts in the literature such as the work of Drake (2001) or Sinko and Peters (1983). More recently Ta'ala (2006) has emphasised the importance that whakapapa plays in defining Māori identity and the breadth of scope that it has beyond family connections and lineage. Given that there is an added element attached to whakapapa that has not been illuminated in 
research on Western concepts of genealogy it would be wise to factor this in to any study investigating the needs of whakapapa researchers.

\subsection{Genealogists and Family Historians}

The relationship that exists between genealogists or family historians and libraries, and therefore librarians has been regularly written about by those in the LIS field such as Latham (2003) though is it only in recent years that research on genealogists or family historians as a "user group" has become more common. This probably reflects the growing popularity of genealogy with Litzer (1997) stating that it is "one of Americans [sic] most popular hobbies."(para. 2). The idea that this popularity is increasing is an oft repeated one in the mainly North American based literature and statistics quoted by Kuglin (2004) suggest that this is also the case in New Zealand. Consequently, a body of research into the needs of this group is now beginning to develop though it is has largely been limited to genealogists in North America and has not, so far, concentrated on indigenous populations. Some research is concerned with how genealogists carry out their research and what their needs, attitudes and motivations are. Research in this area has often used surveys to gather data, such as those by Lambert (1998), Litzer (1997), Sinko and Peters (1983) and Drake (2001).

Despite the long association that genealogists and family historians have had with libraries and archives surprising little research has looked at what sorts of information seeking behaviours these customers utilise, that is, what strategies genealogists use in trying to find the family history information they need. Duff and Johnson (2003) conducted a series of in-depth interviews with American professional genealogists 
and determined that this group tended not to use librarian-produced finding aids, and tended to rely "more heavily on colleagues or an informal network than on archivists" (pg. 94). Duff and Johnson also found that these highly experienced genealogists were very adept at re-framing their information need, such as the name of an individual being researched, into a search for the kind of record that might contain that information, such as a baptism or marriage record. This research was conducted within the context of the use of archives rather than libraries, as well as focusing on experienced users. Kuglin (2004) finds some similarities within the use of libraries in New Zealand specifically in that family historians and genealogists tend to be "quite independent researchers" (pg. 67) with relatively low use of finding aids. The information seeking behaviour of whakapapa researchers has however not be investigated in any of the current literature.

Research on genealogists often focuses on generating a genealogist "profile" and determining their level of involvement in genealogical research. Lambert (1999), Yakel (2004), Drake (2001), and Kuglin (2004) all incorporate a profiling aspect in their research. Drake's survey sought to elicit information about genealogists themselves as well as their level of involvement in genealogy. Drake's was the only study to use an online survey and notably received the highest number of respondents of the three. Kuglin (2004) dedicates a portion of her research to creating a genealogist "profile" with data gained through a survey distributed in several New Zealand libraries. Each of these studies, though using different methods of delivery, often in different countries all paint a similar genealogist "portrait" of a genealogist as an older woman who spends a signficant amount of time on her hobby and is relatively experienced in family history research. 
Kuglin's (2004) research stands out as the sole piece of research on genealogists and their use of library services that is set in New Zealand. Apart from creating a genealogist "profile" the study sought to determinine how genealogists research in libraries and how experienced they are, in order to better understand their informational needs and how to address them. Her conclusion that genealogists would benefit from collaboration between libraries and genealogical societies mirrors Litzer's (1997) findings. Unfortunately the demographic data gained from informants in this study was restricted to age and gender therefore cultural considerations as relates to genealogists researching Māori family history were not illuminated.

Furthermore, Kuglin admits that her survey did not capture sufficient data from inexperienced genealogists and that it paints an incomplete picture that warrants further investigaton. Kuglin's study is also limited geographically to the North Island, and can therefore only represent a part of the overall picture for the country.

\subsection{Indigenous Populations and Libraries Internationally}

LIS professionals internationally have made attempts to assess the information needs of indigenous populations in countries other than New Zealand. Much of what has been written is based on the experience of LIS professionals rather than research, and attempts to make recommendations on how to best serve these customers. This is the case with examples such as Nakata (2005) wherein the information needs of Aboriginal Australians are discussed. Few examples of research that has been undertaken in this area are available however one such is the work of Biggs (2001) who sought to investigate and assess the degree of access to library services available amongst Native American communities in California. Biggs found that the tribal libraries she assessed were seen as an important institution in 
preserving and recording local indigenous culture but that they lacked consistent and established funding. Another example of research into the information needs of an indigenous group is that of Ikoja-Odongo and Ocholla (2004) who focus on

entrepreneurs in Uganda. They found that the information seeking behaviours of this group rarely led them to a library and $68 \%$ of respondents did not know about public libraries at all. A common thread amongst this work is that indigenous populations are often not well served by the Western library model. This is discussed in more detail with respect to the indigenous culture in New Zealand in the following section.

\subsection{Māori, Information Management, and Technology}

Those in the LIS field in New Zealand have recognised for some time that use of information systems such as those found in libraries, and related technology has been problematic for Māori as a user group. There is a body of writing on Māori use of libraries such as that by Szekely (1992) but there are few examples of research in this area. However recent research by Duncker (2002) has sought to investigate this using a combination of research methods including interviews and observed behaviour. In a small-scale study carried out at the University of Waikato Duncker found that Māori students were often uncomfortable in a library environment and unfamiliar with how information was organised in the library. This unfamiliarity also had negative effects on their use of digital library resources as the terminology and organisation used in the digital environment was based on that found in the physical library. Duncker suggests that use of the library metaphor in digital environments "...further augments the difficulties of users with little or no experience of Western libraries." (pg. 229). Duncker's Māori interviewees also related that they were more likely to learn how to use the library more efficiently if another (usually Māori) person 
took a hands on approach in showing them how to use the resources and orient them in the environment. This is a key piece of information to consider when investigating the information seeking behaviour of whakapapa researchers. Although this piece of research was conducted in a tertiary library, there is every reason to suspect that similar problems afflict Māori users of public libraries too. Māori users of public libraries were among those interviewed in the work of Simpson (2005) who interviewed Māori library users and Māori staff at several libraries around the country in order to illuminate how Māori library users access information in a library setting. A preference for human interaction over technology or other finding aids was expressed by many of the interviewees in this study as well.

Two key, related pieces of research that do focus on public libraries have been published. MacDonald's (1993) research used interviews and surveys filled in by staff in public libraries in order to determine how well libraries were catering to Māori customers. Though it highlighted several key points in library use by Māori, its focus was mainly on those providing the service, and whakapapa research was not dealt with. In Szekely's (1997) follow-up study the opinions of both Māori staff and users of the library were gathered through a series of hui or meetings held throughout the country. This piece of research highlighted several issues that apply to the study currently being proposed such as the identification of whakapapa as an "Information need" (pg. 36), attitudes around the appropriateness of libraries holding this information, and a general reticence by Māori in using libraries. Similarly Auckland City Libraries in consultation with Heather Worth (1995) surveyed their customers about their use of that public library network and received similar feedback. No further follow up research has been undertaken in these areas and ten years on it 
may be timely to revisit some aspects of this research study with a focus on whakapapa researchers. Also discussed by Szekely was the difficulty Māori have in dealing with technology such as library catalogues, an idea supported by Duncker's (2002) and Simpson's (2005) findings.

Recent research by Ta'ala (2006) has illuminated the changing role of whakapapa in a records management context. Ta'ala conducted a series of interviews with representatives of Iwi rūnanga (Māori tribal organisations) to determine how whakapapa, a mainstain of a traditional Māori worldview, was being changed by its integration within a western records management system and how tikanga Māori (traditional Māori beliefs and protocols) has been applied in the care of Māori information. Though this research takes place in the context of records management there are aspects of this that could be relevant to public libraries also.

Māori access to technology is the focus of the work of Parker (2003) who used data gathered from interviews and surveys to assess the engagement of Māori with information technologies and found that this demographic suffers from a noticeable "digital divide" meaning that Māori are far less likely to have access to information technologies than the population in general. Public libraries extensively use these technologies in providing access to resources, as well as providing access to the technologies themselves. No research in this area has yet determined how this trend might affect whakapapa researchers. 


\subsection{Summary}

As we have seen there is a body of literature in the LIS field that describes the information needs and characteristics of genealogists and that genealogists in New Zealand bear some similarities to those in other Western countries. It would be a mistake however to extrapolate these tendencies and expect that they will necessarily apply in a Māori cultural setting. There is a distinct lack of literature in this specific area on which to base an opinion, however research that incorporates knowledge of Māori life and culture will go some way to illuminating the needs of whakapapa researchers. 


\section{Research Design}

\subsection{Project Description}

The project objectives determine the nature of this research project. In order to make comparisons with the findings of earlier work in the body of research similar data needed to be gathered. As the only research in this area to have been done in New Zealand, Kuglin's study on the information seeking behaviour of genealogists provides the most relevant and current template on which to base a Māori focused study though some deviation was required in order to tailor this study with respect to specific Māori cultural factors, drawing on the work of Parker (2003), Hemara (2006) and Szekely (1997). The basic format of Kuglin's study was adopted with a crosssectional quantitative survey approach but one which focused on a much smaller population. This strategy was also considered suitable in that time limitations would not allow for a longitudinal approach.

The population that is the focus of the project is smaller than in Kuglin's study because the percentage of New Zealanders who identify as Māori is $14.7 \%$ of the total population, according to statistics gathered during the 2001 census by Statistics New Zealand (2002) (pg. 11). Kuglin's research gathered data from any genealogists regardless of their specific area of interest or ethnicity. This being the case, it was considered necessary to cast a wider net to capture data than was utilised in Kuglin's study. For this reason the study had a broader geographical focus. In addition, with regards to the survey instrument, where other research indicated, or researcher experience suggested that additional or modified questions should be used or other adjustments made, these were incorporated into the study. 
A pilot study was employed to check the feasibility of the questionnaire used and that individual questions were acceptable. After the revised questionnaire (Appendix 2) was distributed and the data was collected, the analysis phase began which involved grouping, and collating data into sets to provide a comparison to the data collected in Kuglin's research. In some cases exact correlations were not possible as modifications to Kuglin's original questionnaire were made but comparable results should be possible in areas such as the creation of a researcher "profile" and in identifying levels of use of specific resources.

In the last phase of the study the analysed data, along with the researcher's own public library experience, and other literature in the field was used to formulate a series of recommendations. These recommendations take the form of key actions or processes that public libraries can take to improve their service to whakapapa researchers.

\subsection{Methodology}

It was decided to follow the structure and methodology of Kuglin's (2004) study reasonably closely in the hopes of producing comparative data. Though some research on genealogists, such as that of Duff \& Johnson (2003) or Yakel (2004), has utilised qualitative methods such as interviews to gather data, this would require the researcher and interviewee to be in the same location. As this study sought to cover as broad a geographical spread of the country as possible this method was ruled out as impractical. As has been stated above this piece of research follows the format used in Kuglin's study of using questionnaires distributed to several libraries in 
New Zealand. There were some differences in terms of the content of the questionnaire and distribution and these will be discussed further in this section.

\subsubsection{Survey}

As has been shown, researchers have successfully used surveys to gather data from genealogists in a number of studies (Drake 2001; Kuglin 2004; Sinko and Peters 1983) and in each case the researcher has gathered enough data from their sample to be able to draw conclusions and make generalisations which they could apply to the whole group. This method has advantages where time limitations and geographic distance make participant interviews, or in a Māori cultural setting group meetings like hui, impractical. This is the case with this study. As noted earlier Drake's survey utilised an online questionnaire and was extremely successful at capturing data, with over 4000 completed responses and was successful in attracting younger respondents. In this study a printed survey was distributed at public libraries as well as 'Deing accessildie on'ine. T'ne survey was anonymous with no identifying information being elicited from participants who took part on a voluntary basis.

\subsubsection{Pilot Survey}

In order to assess how well Kuglin's questionnaire translated to a more specific population, namely whakapapa researchers, the pilot survey was distributed to selected participants for appraisal and feedback. The pilot survey included the questions as they would appear in the final questionnaire and included adjustments and additions made to Kuglin's original survey instrument. The pilot survey had the format of the final survey incorporating Likert scale and multiple choice questions.

Pilot participants were asked to comment on issues such as the length of the survey (both in number of questions and in time taken to complete it), whether the questions 
were clear and easy to understand, whether there were any questions or answer options that were missing and should be included, and any other comments or feedback that they thought pertinent or useful. As the pilot questionnaire needed to be distributed to people who were familiar with whakapapa research, the questionnaire was made available to members of Te Rōpū Whakahau (TRW), the national organisation for Māori in the LIS field via the TRW email list-serv. An email Letter of Information explaining the purpose of the proposed study and the need for considered feedback was sent with the questionnaire attached as a word document and was distributed from 20 June 2007. Responses were accepted until 31 June 2007. In addition to the distribution via email, questionnaires were administered by the researcher to 2 Māori colleagues in order to be able to discuss their comments and ideas around the questionnaire. Pilot questionnaires were completed by 7 respondents in total and the comments were generally very positive about the content of the questionnaire, though some points were raised that led to adjustments being made.

One respondent found that Question 1, option a. "for posterity" might not be clear to all potential respondents and that this could be explained in more detail. As a result a fuller explanation of the term was included in this question option. Another respondent felt that the year range offered in Question 2 which asked how long someone had been involved in whakapapa research was too narrow. Given that past research, as mentioned earlier, has profiled genealogists as being "elderly" it was considered a fair point to make and as a result the year range was extended by 5 years. 
All respondents to the pilot survey completed the questionnaire fully and were able to follow the instructions well. Estimates on how long respondents took to fill in the questionnaire ranged from 5 to 15 minutes. These results suggested that the questionnaire, with minor adjustments, would be suitable for wider distribution.

\subsubsection{Survey Instrument - Printed}

Printed questionnaires were distributed to the public libraries in Manukau, Auckland, Wellington, Christchurch and Dunedin along with instructions to staff in those libraries on the content and purpose of the study. Each questionnaire was accompanied by a Letter of Information explaining the purpose of the study, what the data would be used for, the cut-off date for receipt of completed surveys, and an estimate of how much time it should take to complete. The questionnaires were distributed from the central library in each city and staff at these sites were asked to place the questionnaires in the area where the family history or Māori resources of that library are kept. Appropriate managerial permissions were gained before any questionnaires were distributed and as part of this process the most suitable staff member to act as a contact person was identified. Each host library was given the option of receiving a breakdown of results relating to their customers at the completion of the project. Information forwarded to the host libraries would not identify individuals and would take the form of aggregate data.

In keeping with Kuglin's study, the individual libraries in which the survey was distributed were the "main" or central library where the core New Zealand (and therefore Māori) heritage resources are held. These libraries were -

- Auckland City Libraries, Central City Library, Auckland Research Centre

- Manukau Libraries, Central Research Library 
- Wellington City Libraries, Central City library, New Zealand Collection

- Christchurch City Libraries, Central City library, Aotearoa New Zealand Centre

- Dunedin Public Libraries, City library, 3rd floor

A dropbox was made available at each of these distribution points for respondents to use but a freepost address and self addressed envelopes were also provided as Kuglin's experience showed that many more surveys were submitted via mail than were deposited in the boxes provided. In this study this proved not to be the case, though some completed questionnaires were received in this way, particularly those accessed online. In addition Kuglin's use of different coloured paper for different locations was employed in this study to help increase efficiency in the data analysis phase of the project. In order to gather enough completed questionnaires to have a large enough sample to work with (see 4.2 Population and sample) 40 questionnaires be distributed to each of these sites.

Distribution of the printed survey occurred between 16 August 2007 and 5

September 2007 with the cut-off date for receipt of completed surveys set at 10 September 2007.

\subsubsection{Survey Instrument - Online}

Online access to a printable version of the questionnaire was provided to allow respondents not able to visit the five distribution sites to take part. The questionnaire distributed online had exactly the same content as the hard copy questionnaire and also included a Letter of Information. This PDF version of the printed questionnaire was hosted by the website of the Māori Interest Group - New Zealand Society of Genealogists ( http://rcyachts.net/maori/ ) and was made available from 16 August 
2007. Potential respondents were instructed to print out the questionnaire and send it to the freepost address. Posted replies were accepted until 10 September 2007.

Though Kuglin used local branch meetings of the NZSG to distribute questionnaires directly to genealogists, this was not an option in this research. Because the sites of distribution used in this study were spread across the country it was practical for the Christchurch based researcher to attend local meetings. In addition the Māori Interest Group, which comprises of whakapapa researchers and is therefore the target demographic for the questionnaire, is a national group of roughly 50 individuals ${ }^{3}$, spread geographically across the country. It was not possible for the researcher to attend a branch meeting as the members of this group do not regularly meet. The possibility of utilising the group's mailing list to send questionnaires directly to group members was also out of the question as this would contravene the Privacy act (1993) and as a result it was decided that a PDF version hosted from the the group's website would be the best way to make it available to members, as well as to interested non-members.

As well as making the members of MIG-NZSG aware of the questionnaire through their newsletter links to the PDF document were posted on the researcher's project blog www.searching4tupuna.blogspot.com and via the noticeboard of an online whakapapa club http://whakapapa.maori.org.nzl .

\footnotetext{
${ }^{3}$ Joyce (2007)
} 


\subsubsection{Survey Content}

The content of the questionnaire (Appendix 2) was similar to that previously used by Kuglin (2004) (pp. 26-28) and was grouped into the following categories -

- Whakapapa research experience and interest

- Finding the information you need in the library

- Librarian provided assistance

- Computer knowledge and experience

- General information about you

However there were changes to question options provided to make them more relevant to users of Māori information sources, and where necessary additional questions were included, for instance in the "General information about you" section, in order to highlight demographic information needed to answer the research questions of the study. Some questions used in Kuglin's study were omitted in the interests of keeping the questionnaire to a size that would not make it too time consuming for respondents to complete.

\subsection{Population and Sample}

The target population to be surveyed was people who use public libraries in New Zealand to do whakapapa research. For the purposes of this study there was no restriction on the ethnicity of the researcher, though it was considered likely that the vast majority of those completing the survey would have Māori ancestry. Participants self-selected through their voluntary participation. A sample size of $70-80$ was selected as a target response rate for the survey with the aim of gathering around 12 responses from each site. This was in anticipation of a roughly $50 \%$ return rate based 
on Kuglin's experience. In reality a much lower response rate occurred in this study with only a $12.5 \%$ return rate achieved. Given the differences in percentage of Māori population living near these sites it was also anticipated that there would be some differences in the level of response. Though the results of previous research has shown the age of genealogists to be middle-aged to elderly, in the context of whakapapa research, the researcher's experience suggested that there may be more younger people involved in this pastime than in other groups previously studied. Conversely, this study was expected to confirm the gender of whakapapa researchers as predominantly female, a idea supported by previous research on other populations.

\section{Data Analysis}

\subsection{Introduction}

On completion of the data gathering phase of the study the data analysis began. Again Kuglin's template from her earlier study was applied here. Sets of data were collated that reflected those used in Kuglin's study. Direct correlation has not always been possible in instances where different multiple choice options have been used to reflect, for instance, specific sources that contain information relevant to whakapapa research that were not included in Kuglin's study. However comparisons in areas such as age and computer experience, are direct correlates. Where data for a specific question or group of questions had noticeable deviations for the site of distribution these have been highlighted. It was anticipated that this might be the case with questionnaires accessed online. For example, respondents who used this method of distribution might be more likely to rate themselves as experienced computer users. In addition it was anticipated that there might be differences in 
library use between respondents who had Māori ancestry and those who did not.

Data from all questions was analysed to see if any noticeable variations occurred. In most cases the gathered and analysed data has been expressed as percentages. This method has the advantage of making comparisons with data gathered in earlier studies such as Kuglin's easier despite there being different levels of response involved. Where percentages have been used these have been rounded to the nearest whole number. In circumstances where this rounding caused either a slight excess or deficit, with the total percentages adding up to more or less than 100 percent, the difference has been subtracted or added to the option with the largest percentage result. In keeping with Kuglin's study the data has been represented in the form of graphs or tables.

Where a question was not fully completed or missed by a respondent this question has been considered void. Other questions on the same questionnaire were still included for analysis assuming that they were filled in correctly. It was anticipated that at least some of the survey questions would be inaccurately completed by respondents but the inclusion of a pilot study was considered to have lessened the likelihood of this occurring.

It was hoped that the utilisation of 5 distribution sites at public libraries in different parts of the country would create a fuller picture of whakapapa researchers around the country, however there was much variability in response at different sites.

Despite questionnaires being prominently displayed in the Genealogy Room of the City Library no responses were received from Dunedin Public Library customers. This is almost certainly to do with the much lower level of Mãori population in this city 
than in others, with only $1.2 \%$ of the Māori population of New Zealand residing in this city $^{4}$. As a result no data for Dunedin Public Library customers was gathered and will not feature in the analysed data.

There were also no responses from Auckland City Libraries customers.

Unfortunately questionnaires completed by these respondents were not returned in time to be included in this research. Auckland City Libraries customers completed 15 questionnaires but they do not feature in the analysed data. The researcher hopes to be able to incorporate this data into any future articles or conference presentations on this topic.

Of the remaining 3 libraries that did manage to garner customer responses, the only site that reached the target of 12 or more completed questionnaires was Manukau Libraries which was the source of 13 completed questionnaires. Given that Manukau is home to $8.4 \%$ of the Māori population of New Zealand ${ }^{5}$ this higher number of responses is not surprising. Christchurch City Libraries customers completed and returned 11 questionnaires and Wellington City Libraries customers completed 3 questionnaires. In addition 5 respondents used the questionnaire that was made available online. The following analyses is based on these 32 responses, though some individual questions may have slightly fewer responses due to questions being incorrectly completed in some cases.

It was hoped that some comparison would be able to be made between Māori and non-Māori respondents however only 3 individuals identified as non-Māori and this

\footnotetext{
${ }^{4}$ Statistics New Zealand (2001)

${ }^{5}$ Statistics New Zealand (2001)
} 
small number was not considered by the researcher to be significant enough that conclusions could be confidently drawn from this data. Similarly the small number of responses from the Wellington distribution site meant that analysing data specifically from this site was problematic in terms of being statistically meaningful. However the number of responses from the Christchurch and Manukau sites meant that trends and/or patterns of data for these sites were more obvious.

In keeping with Kuglin's study the level of research experience of whakapapa researchers was investigated in terms of the length of time that the respondent had been involved in the "hobby", how often they visited a public library for the purpose of this research, and how much time was spent there, and how much research experience these researchers had prior to their interest in whakapapa. In addition, the strategies and behaviours that whakapapa researchers utilise when they are in a public library are examined by looking at the what research activity they employ on their first and subsequent visits to an unfamiliar library, by determining their preferred methods of locating relevant resources, be it by shelf-browsing or library catalogue use, as well as the level of information literacy employed by researchers in their use of footnotes, bibliographies, and instructions to specific resources. The degree to which whakapapa researchers use computers in their research is also examined.

Demographic information gathered via the questionnaire is used to create a whakapapa researcher "profile" and compared to similar profiles in the existing literature. 


\subsection{Whakapapa Researcher Profile}

\subsubsection{Age, Gender and Ethnicity}

The researcher's public library experience led her to suspect that whakapapa researchers might be younger on the whole than genealogists that have been studied in earlier research. Kuglin (2004) found that $54 \%$ of respondents were aged 61 years or older and these results were very much in line with North American data gathered by Lambert (1998) and Drake (2001). In this study respondents were noticeably younger with $69 \%$ of respondents being under 51 years of age (Chart 1)(Appendix 2 , Question 22). In particular respondents from Manukau were much younger, with more than half the respondents falling within the relatively youthful age range of $21-$ 30 years. No respondents from Manukau were older than 50 years. This may be partially explained by the fact that Manukau is a comparatively youthful city with an average age 4 years younger than the national average, however it seems unlikely that this could account completely for the absence of any elderly or retirement age whakapapa researchers. Further research into users at this library may be required to more fully understand the high numbers of younger whakapapa researchers found there.

\section{Chart 1.}

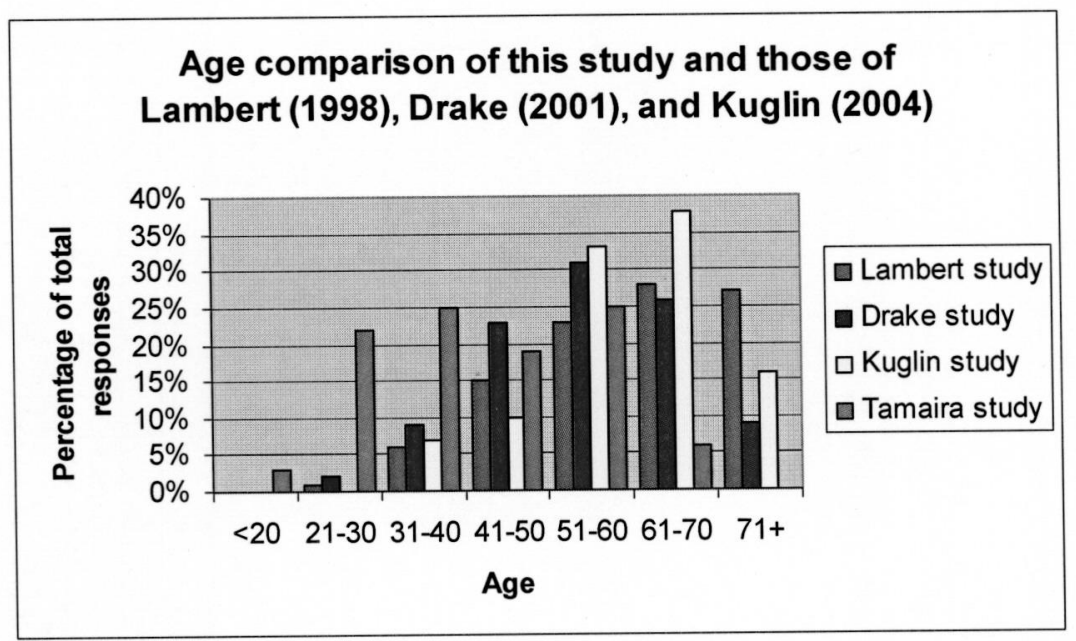


Although the age of whakapapa researchers differs significantly from those investigated in earlier research, in terms of gender, results were quite similar to other studies. In this study there was a slightly lower percentage of female researchers (59\%) than Kuglin (2004) and Drake (2001) but this was similar to Lambert's (1998) results (Chart 2)(Appendix 2, Question 21). In all of the research undertaken female researchers have significantly outnumbered males and this tendency is confirmed by the data in this study also.

Chart 2.

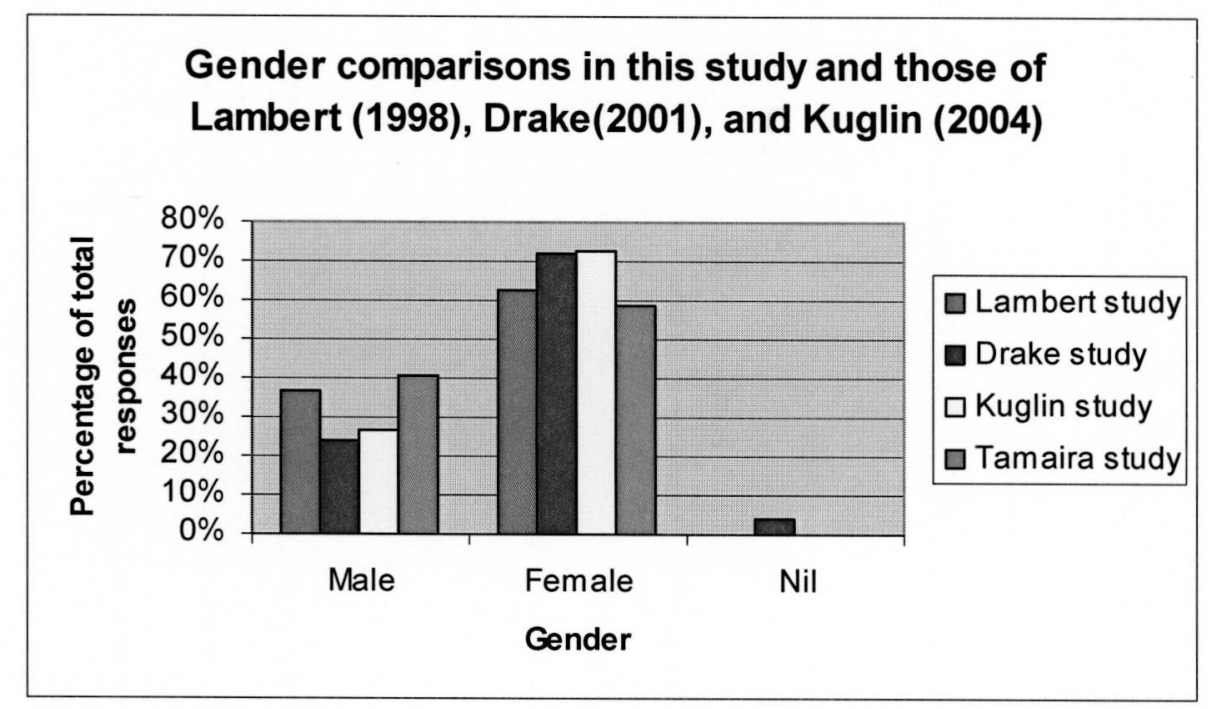

As expected the vast majority of respondents had Māori ancestry (Chart 3). It was the researcher's experience however, that whakapapa researchers were not exclusively those with Māori ancestry and this was confirmed by the 3 respondents who identified themselves as non-Māori. This question (Appendix 2,Question 23) was included to get some idea of how many whakapapa researchers fit into this category as no previous research has looked at this and it was hoped that data from other questions could be analysed with reference to the ethnicity of the respondent. Due to the small number of non-Māori respondents it was decided that this would not provide meaningful results. 


\section{Chart 3.}

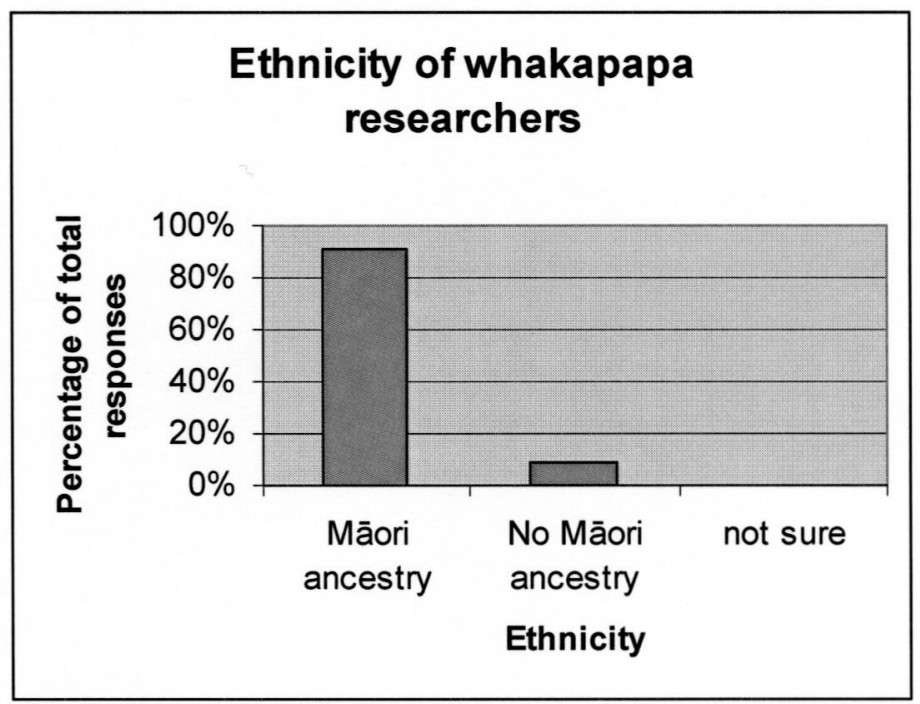

\subsubsection{Previous research experience}

Determining the level of research experience of whakapapa researchers was done through asking several questions including how often they visited the library before they became interested in whakapapa research (Appendix 2, Question 25). Respondents were also asked whether or not they had ever used a library to research an article or report that they had written (Appendix 2, Question 26). Kuglin (2004) found that $58 \%$ of respondents used a public library at least 2 to 3 times a month prior to their involvement in genealogy research. In this study the percentage was slightly higher, with $62 \%$ visiting that often (Chart 4). A higher percentage of whakapapa researchers had also researched an article or report in a library with $48 \%$ of respondents stating that this was the case. In Kuglin's (2004) study only $39 \%$ of respondents claimed to have done this. These results seem to suggest that whakapapa researchers are reasonably experienced library users, perhaps more so than genealogists generally. 
Chart 4.

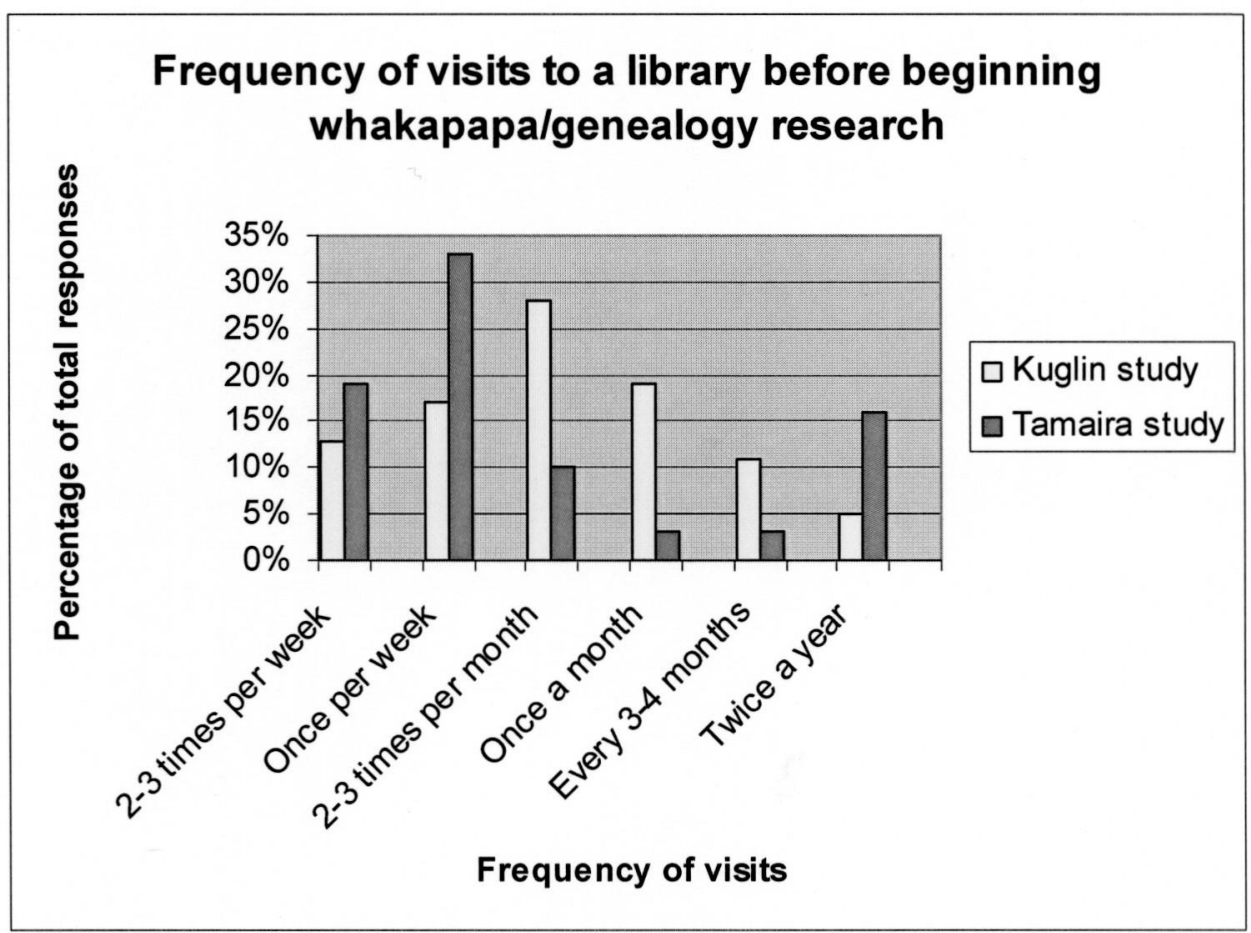

\subsubsection{Motivation for beginning whakapapa research}

Whakapapa research in a Māori cultural context has historically been deeply rooted in identity, often with a spiritual aspect for the researcher. This has been discussed by researchers such as Hemara (2005) and Ta'ala (2006). Kuglin (2004) surveyed genealogists regarding their motivations for becoming involved in this research and this study sought to make a comparison to see if there were any differences in motivation between genealogists generally and whakapapa researchers, given these cultural factors. The nine options that Kuglin used were also used in this study, though some wording was changed slightly, in particular option f. (Appendix 2 , Question 1) which was changed from "for religious reasons" to "for religious/spiritual reasons" in the hope that a slightly broader interpretation would allow Māori respondents to identify their spiritual beliefs relating to whakapapa as a motivating factor. Additional options were also provided to allow those who had started 
researching whakapapa in order to gain some benefit from an iwi/tribal organisation.

This process is discussed at length by Ta'ala and it has been the experience of the researcher that these might be significant options for Māori respondents.

\section{Chart 5.}

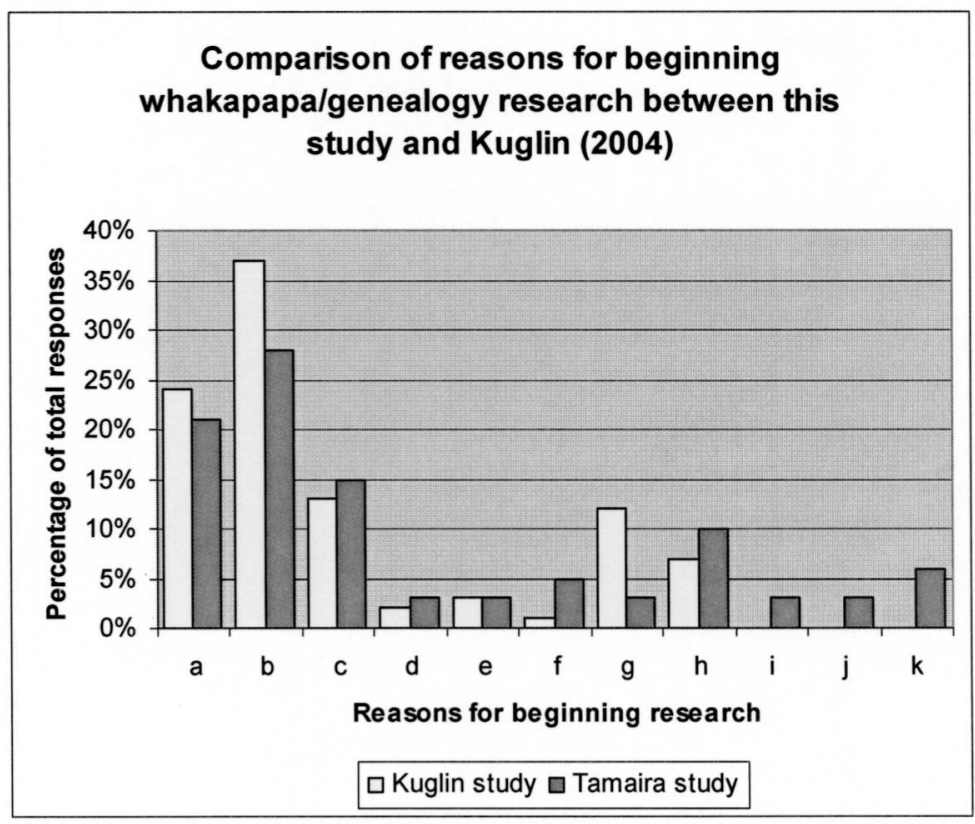

\section{Legend}
a. For posterity (to keep a record for future generations)
b. To learn about my roots, about who I am
c. To carry on work already begun by another family/whānau member(s).
d. To keep my whakapapa researcher wife/husband/partner company
e. To trace medical conditions in a family tree
f. For religious/spiritual reasons
g. For employment (as a paid researcher)
h. to meet living relatives
i. Because I enjoy the company of other whakapapa
researchers/genealogists
j. I had to provide whakapapa to qualify for an education grant/scholarship (Tamaira study only)
k. I had to provide whakapapa to register with my iwi (Tamaira study only)

Results for this question were quite similar to those found by Kuglin (2004) (Chart 5) with option b "to learn about my roots, about who I am" the most popular answer in both studies. Notably, several respondents in this study felt that religious/spiritual reasons was a motivating factor in their whakapapa research, and though this did not rate as highly as other options it was significantly higher than in Kuglin's study suggesting that there may well be a spiritual aspect to whakapapa research. Future study might be able to shed more light on this aspect of whakapapa researchers' motivations. In addition, gaining iwi/tribal benefits were found to be only moderately important motivations for beginning whakapapa researchers. 


\subsubsection{Whose ancestors are being researched?}

Respondents were asked whose ancestors they investigated in their whakapapa research (Appendix 2, Question 24). It was assumed that Māori respondents would largely be researching their own ancestry so this question was included to get some insight into the motivations of non-Māori whakapapa researchers. Though there was only a small number of non-Māori respondents, each one reported that they

researched the whakapapa of their spouse. In the researcher's library experience this is a common reason for non-Māori researchers to be involved in whakapapa research, though further study that gathers data from a larger number of respondents would be needed to confirm this.

Amongst Māori respondents, overwhelmingly researchers were researching their own whakapapa, however not insignificant numbers of respondents reported that they researched on behalf of others, even those not related to themselves (Chart 6). On the whole research was undertaken for themselves and their descendants, which to some degree reflects the popularity of option a "for posterity (to keep a record for future generations)" in question 1 (see 5.2.3 Motivation for beginning whakapapa research).

\section{Chart 6.}

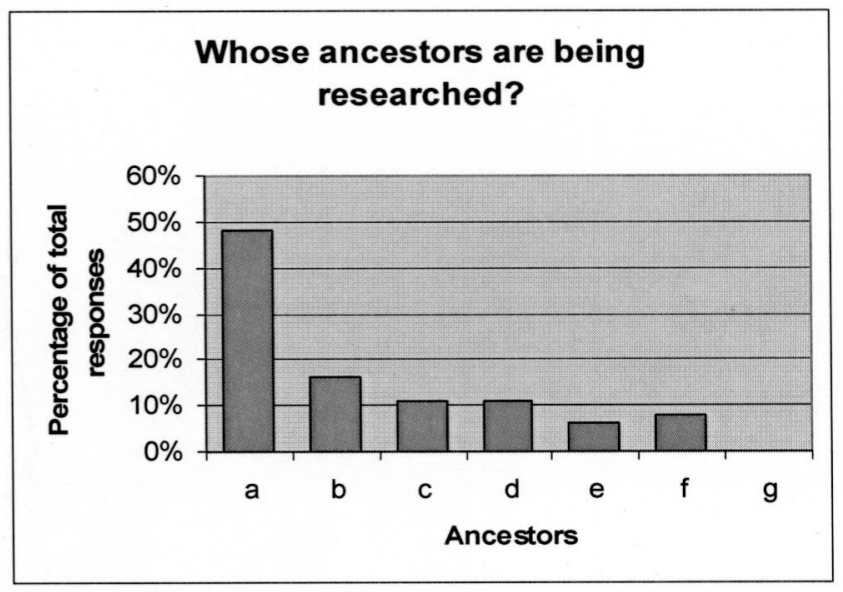

\section{Legend}
a. my own
b. my spouse/partner's
c. my friend's
d. my children's
e. my grandchildren's
f. those of other genealogists/whakapapa researchers
g. those of a client, as a paid researcher 


\subsection{Whakapapa research experience}

\subsubsection{Level of whakapapa research experience}

Kuglin (2004) used a series of three questions to determine the level of experience that respondents had in researching genealogy. This was done with the view that level of researcher experience can have a significant impact on the level of service delivery required from library staff. These same questions were utilised in this study in order to compare the research experience levels and perhaps determine if different levels of staff interaction might be necessary with whakapapa researchers.

Respondents were asked how much time per month they spent on their whakapapa research and how many years they had been researching whakapapa (Appendix 2, Question 3 \& 2). In her study Kuglin (2004) took the data from these two questions and established a formula for categorising researchers as either beginner, intermediate, or experienced researchers. Different levels of researcher experience were defined in the following way-

- Beginner researchers were those who spent less than 1 hour per month for up to 4 years on their research.

- Intermediate researchers were those who spent $1-3$ hours per month for up to 4 years on their research.

- Experienced researchers were those who spent at least 4 hours per month for

3 or more years on their research. (pg. 11)

This researcher found these categories problematic in that not all respondents could be successfully categorised this way. For instance a respondent who had been involved in whakapapa research for over 10 years but only spent $1-3$ hours per 
month on their research did not fit into any of these categories. As a result this categorisation as beginner, intermediate, or experienced researcher was not used in this study. As such, comparisons with Kuglin's results using these categories cannot be made. Instead, comparisons of the results for the individual questions are discussed.

Kuglin (2004) found that $79 \%$ of respondents to her questionnaire had been doing their research for 5 years or more. In this study the percentage was significantly less, with only $47 \%$ of respondents having been involved in research for that amount of time (Chart 7). This is not so surprising given that Kuglin's population sample was signifcantly older than the one studied here. When analysed by respondent age, $80 \%$ of those who reported they had been involved in whakapapa research for this amount of time were over 40 years of age. Similarly younger respondents were less likely to have spent more than 2 years on this kind of research.

Chart 7.

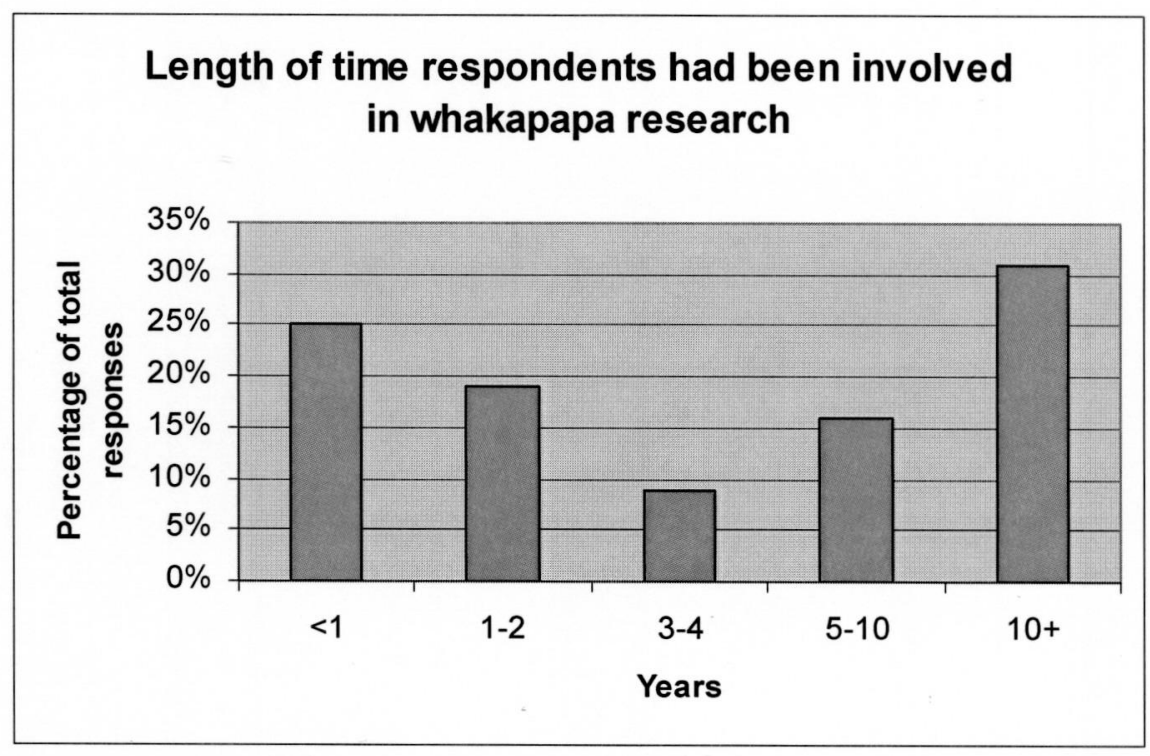

The amount of time spent on research was also compared, with whakapapa researchers generally spending less hours per month on their research (Chart 8). 
Taken together, this data suggests that whakapapa researchers have less experience doing their research than genealogy researchers generally. As such they may require more help or guidance from library staff (see 5.4.5 Asking a librarian for help).

Chart 8.

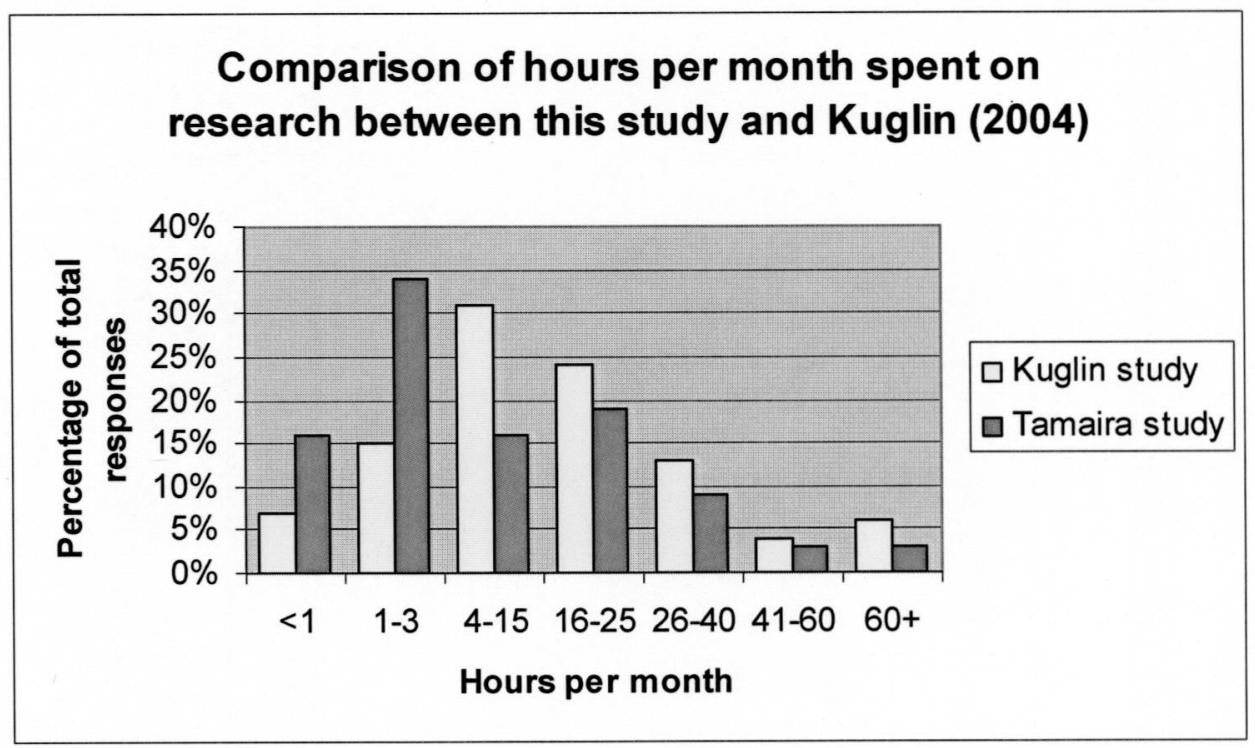

In addition to the amount of time spent, respondents were also asked about what different institutions they visited to do their research (Appendix 2, Question 4). In determining the level of research experience of respondents Kuglin considered that those visiting numerous different repositories with different classification systems and finding aids would have gained valuable research experience by doing so. For this study the options offered to respondents were adjusted slightly, with options such as a Marae-based library, or Iwi runanga whakapapa unit/office being added. In addition the option of travel overseas was removed since it is assumed that whakapapa research material will be primarily New Zealand based.

The most frequently ticked item was "local public library" with "public library in another city or town" as the second most ticked option (Table 1). Kuglin's results for 
this question showed a strong preference for the National Library of New

Zealand/Alexander Turnbull Library but this is partly due to most of her respondents being from the Wellington region in which this library is located. Latter Day Saints (Mormon) family history centres also rated highly in that study and received the same number of ticks as "local public library". This was not the case here, possibly because such centres do not contain as much information about Māori genealogical information as other institutions. Kuglin also found that when the number of items ticked was divided by the number of respondents there was an average of 6 institutions per respondent. In this study 130 items were ticked resulting in an average of 4 institutions per respondent.

Table 1. Institutions used for whakapapa research in order of frequency of choice made by all respondents

\begin{tabular}{|l|r|}
\hline Institution & Number \\
\hline Local public library & 29 \\
\hline Public library in another city or town & 17 \\
\hline Archives New Zealand (National Archives) & 13 \\
\hline $\begin{array}{l}\text { National Library of New Zealand/ } \\
\text { Alexander Turnbull Library }\end{array}$ & 11 \\
\hline Local museum or museum library & 10 \\
\hline Latter Day Saints (Mormon) Family History Centre & 10 \\
\hline Museum or museum library in another city or town & 9 \\
\hline Iwi rūnanga whakapapa unit/office & 9 \\
\hline Marae-based library & 8 \\
\hline Genealogical society library & 6 \\
\hline $\begin{array}{l}\text { Other: written responses included Whānau members, Māori Land Court, } \\
\text { Kaumatua/Elders }\end{array}$ & 8 \\
\hline Total number of ticks & $\mathbf{1 3 0}$ \\
\hline
\end{tabular}

The researcher was interested to note that 9 respondents selected public libraries as the only institutions that they used. Of these 9 researchers, 7 had been involved in whakapapa research for less than 2 years. This suggests that the public library is a starting point for some whakapapa researchers. They may use this as jumping off point to visiting other less publicly accessible institutions as their research experience progresses. Whether this is the case cannot be determined from the current study but would be an area for further research. In addition, though this question asks 
about institutions that respondents have visited 5 respondents wrote in that they had specifically visited whānau/family members or knowledgeable tribal elders for the purpose of researching whakapapa. This is possibly an option or added question that could be included in a future version of the questionnaire. This reflects one of the information seeking behaviours that has been highlighted by researchers like Simpson (2005) and Duncker (2002) with regards to Māori customers preferring to receive information from individuals rather than other resources.

The results from this set of questions, when compared with Kuglin's (2004) seems to suggest that whakapapa researchers do not have as much research experience in their hobby as genealogists in general.

\subsubsection{Whakapapa research in public libraries}

Though respondents had been asked how much time they spent on their research per month, they were later asked how often they visited, and how much time they

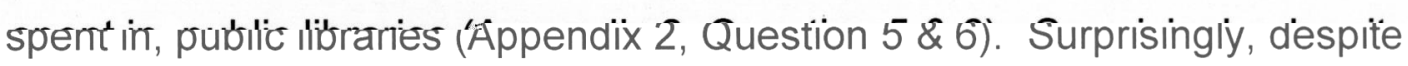
whakapapa researchers not seeming to be as experienced researchers, they reported higher levels of library use (Chart 9). Almost half of respondents (48\%) reported that they visited a public library for whakapapa research at least weekly. This is significantly higher than Kuglin's $30 \%$ of genealogists who visited once or more per week. 


\section{Chart 9.}

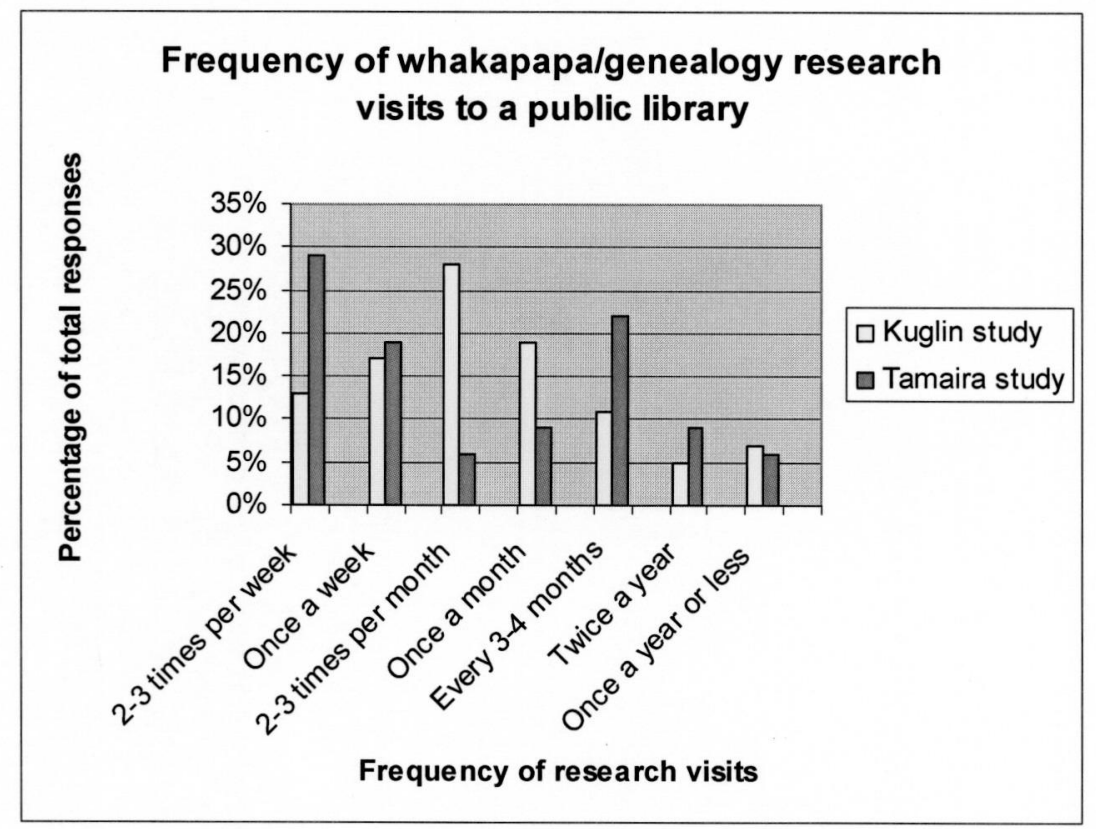

Chart 10.

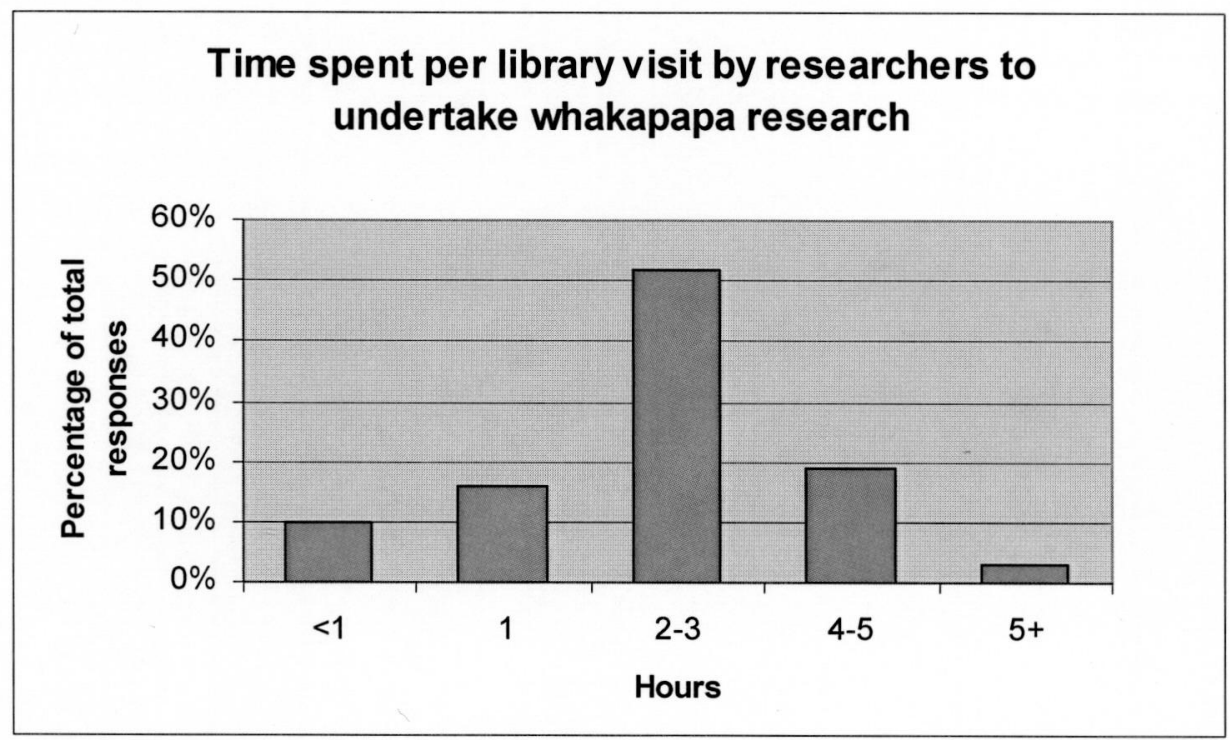

Despite visiting more often, the amount of time spent per visit by whakapapa researchers compared with genealogists seems to be about the same (Chart 10). In Kuglin's study just over $50 \%$ of respondents spent 2-3 hours per visit. From this data it seems clear that both genealogists and whakapapa researchers are frequent public library visitors who spend significant amounts of time there on their research. 


\subsection{Finding whakapapa information in public libraries}

\subsubsection{Order of research activity in the library}

Kuglin (2004) set about determining which information seeking behaviours genealogists would employ when in an unfamiliar library. Respondents were asked what their first "port of call" would be in a library they had not visited before (Appendix 2, Question 7). They were then asked what their first action would be if they visited this library again (Appendix 2, Question 8). These same questions were used in this study though additional options were given. The researcher was interested to know if given the option of consulting a genealogy reference librarian or a Māori reference librarian which whakapapa researchers would be more likely to do. Similarly respondents were able to choose to browse the genealogy shelves or the Māori collection shelves. In each case respondents were more likely to choose Māori specific resources or staff than those dealing with genealogy generally (Chart 11).

\section{Chart 11.}

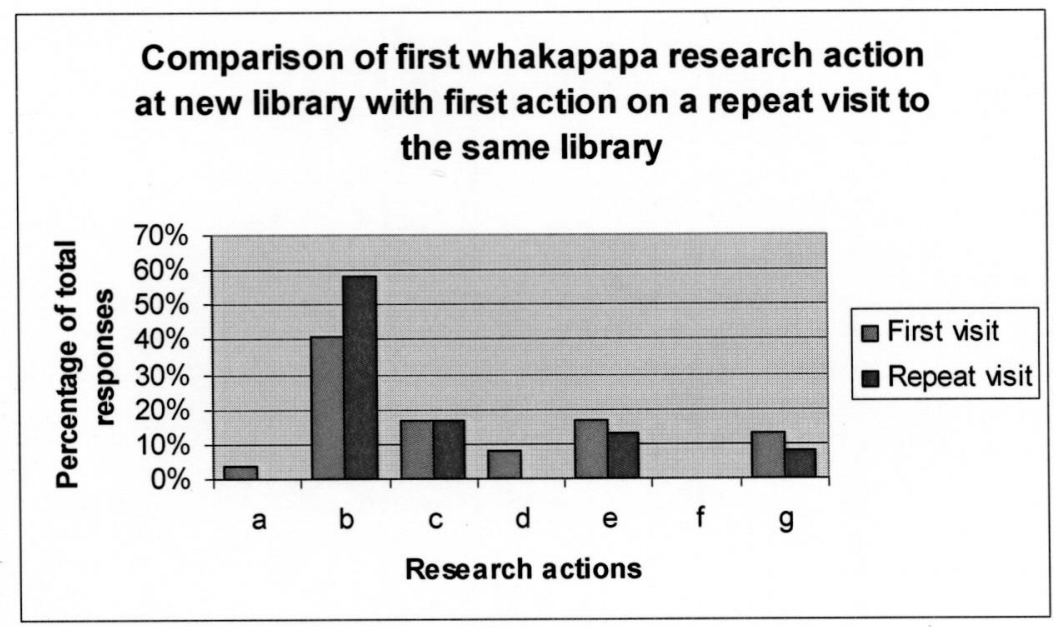

\section{Legend}

a. Consult the genealogy reference librarian

b. Consult the Māori reference librarian

c. search the library catalogue

d. browse the genealogy shelves

e. browse the Māori collections shelves

f. look for a brochure or other printed guide to introduce me to the collection

g. use the online whakapapa sources

There was also a marked difference from Kuglin's results which showed that consulting a staff member rated highly as a first visit strategy but dropped in the subsequent visit. This study had opposite results as consulting the Māori reference 
librarian was the most popular option on the first visit and increased on the subsequent visit. Duncker's (2002) research at Waikato University that emphasised the importance of face to face (kanohi-ki-te-kanohi) interaction as the preferred method of acquiring information for Māori library users is seemingly supported by this data. Also worth noting was that brochures or printed guides were not the preferred option for any of the respondents. As a first "port of call" in a public library it seems that whakapapa researchers are more interested in speaking with knowledgeable staff members than in printed guides or brochures.

\subsubsection{Using whakapapa sources}

In order to determine which sources of information were being used for whakapapa research purposes respondents were given a list of possible sources and asked to tick any that they might use (Appendix 2, Question 9). This question was presented slightly differently from Kuglin's study which asked researchers to rank the sources by importance. Due to the length of the list supplied it resulted in a number of questionnaires being rejected in that study. To avoid this problem respondents were not asked to rank the options provided but merely indicate which ones they used in their whakapapa research (Table 2).

Table 2. Sources commonly used by whakapapa researchers

\begin{tabular}{|l|r|}
\hline Source & Number \\
\hline Māori Land Court/Te Kooti Whenua Māori records & 25 \\
\hline Births, deaths, marriages index & 20 \\
\hline Electoral rolls & 16 \\
\hline Published genealogies or family histories & 16 \\
\hline Cemetery/Urupa records & 15 \\
\hline Waitangi Tribunal reports or evidence & 13 \\
\hline Church records & 10 \\
\hline Military records & 9 \\
\hline Other land records & 9 \\
\hline Census records & 7 \\
\hline Telephone/postal directories & 6 \\
\hline Other - written in included whānau, books relating to the tribal area, Index of Māori names, \\
George Grey collection, iwi newspapers & 6 \\
\hline Total number of ticks & $\mathbf{1 5 2}$ \\
\hline
\end{tabular}


It is important that library staff know which sources are likely to be in demard for whakapapa research not only for acquisition of suitable sources but also for improving access to those already owned by the library. The most frequent/ selected item was Māori Land Court records. There are indexes for some lāori Land Court Minute books, both available as CD-ROM or subscription databse. Given that this seems to be a highly used source by whakapapa researcher it will be to their benefit to have access to these indexes. Also, it is worth considerin which sources might be better utilised if they were sited within a Māori collection rther than as part of a genealogy collection.

Also worth noting is that both Births, deaths, and marriages indexes and Elctoral rolls (2nd and 3rd most selected sources respectively) have sub-sections, c separate indexes for Māori individuals during some time ranges. This meas that these very popular sources are potentially more complicated to use for whaapapa researchers, who may have to check both the Māori, and general roll or indx. Library staff should be aware of the added complexity of these sources witrrespect to whakapapa research, as it may mean that more staff help is needed, at last in the beginning.

In Kuglin's study Census records ranked very highly in this question but dichot appear to be a preferred option for whakapapa researchers. This is probaly due to the fact that many census records for the United Kingdom, which contain prsonal information about individuals, are now available online. Though New Zealad census information is only available in the form of aggregate data, and doe not feature individuals' information, some regional historical censuses for Māor 
populations exist and do contain individual and family names. However these are not widely publicised and are often "buried" within larger works such as Waitangi Tribunal evidence, or the Appendices to the Journal of the House of Representatives. This is most likely the reason that whakapapa researchers do not make use of these kind of records as often as other genealogists might.

Ranking what tools whakapapa researchers used that found most useful information for their research was the subject of the next question (Appendix 2, Question 10). Although there were only 6 options given that respondents needed to rank, this proved difficult for some respondents, with 7 questionnaires being considered void for this question, usually because the same ranking was used for more than one option. The most notable difference between results in this study and Kuglin's (2004) was the high use of fiche/CD-ROM indexes that Kuglin found. In this study whakapapa researchers surveyed ranked this as lowest. This could be due to the fact that microfiche indexes form a large part of the resources held at Latter Day Saints (Mormon) family history centres, an institution that many respondents in Kuglin's used.

The table below shows the strategy that received the most ticks for a particular ranking (Table 3). Asking a librarian for help was ranked as the most useful strategy, compared with its third place ranking in Kuglin's study, though this was the option most often ranked fourth as well. It seems that some whakapapa researchers rate the help of librarians, while others prefer alternate methods (Appendix 3 , Aggregate data). 
Table 3. Strategy that most frequently finds a source useful to whakapapa research

\begin{tabular}{|r|l|r|}
\hline Rank & Strategy & Number \\
\hline 1. & By asking the librarian & 11 \\
\hline 2. & By checking the computer catalogue & 11 \\
\hline 3. & By reading a printed brochure or guide & 7 \\
\hline 4. & By asking the librarian & 6 \\
\hline 5. & By consulting a fiche or CD-ROM index & 10 \\
\hline
\end{tabular}

Asking the librarian was ranked number 1 by $60 \%$ of respondents from Manukau and was a noticeable deviation from what was represented by data from other dstribution sites. The reasons for this are not known but it may be that librarians at the Manukau distribution point are considered more approachable by their customers than those from other sites, or it may be due to the comparative youth of Manukau respondents. This is an area that could be investigated further as it would certainly be worthwhile for the library profession in New Zealand if there are particular strategies or processes at play that make whakapapa researchers at Manukau libraries more likely to ask for librarian assistance than elsewhere in the country.

\subsubsection{Using sources of information effectively}

Familiarity with sources of whakapapa information can come from repeated use, being shown how to use the resource by a staff member or other person, or by using instructions or an introduction that accompanies that source. Sources can also lead to other sources through footnotes and bibliographies. A degree of information literacy that allows a researcher to use the tools at their disposal to figure out how to more effectively use a source may have repercussions in terms of their degree of dependence on library staff. To determine how effectively whakapapa researchers use the sources they find, they were asked 2 questions about introductions and instructions, and bibliographies and footnotes (Appendix 2, Question 11a \& b). Compared with Kuglin's results, whakapapa researchers displayed much less use of 
these tools. A sizeable $45 \%$ of respondents reported that they never or seldom used the introduction or instructions of a source compared with $11 \%$ in Kuglin's study (Chart 12). Similarly $39 \%$ of whakapapa researchers reported that they never or seldom used footnotes or bibliographies compared with only $15 \%$ in the research conducted by Kuglin. This suggests that whakapapa researchers are not using sources as effectively as they could be and that there may be opportunities to improve this through user education programmes. Interestingly, the use of bibliographies and footnotes seems to be more frequent than that of introductions and instructions among whakapapa researchers, perhaps as these tools can be very useful in tracking down another source. It is possible that this comparative lack of information literacy may have some effect on how heavily whakapapa researchers rely on library staff for assistance.

\section{Chart 12.}

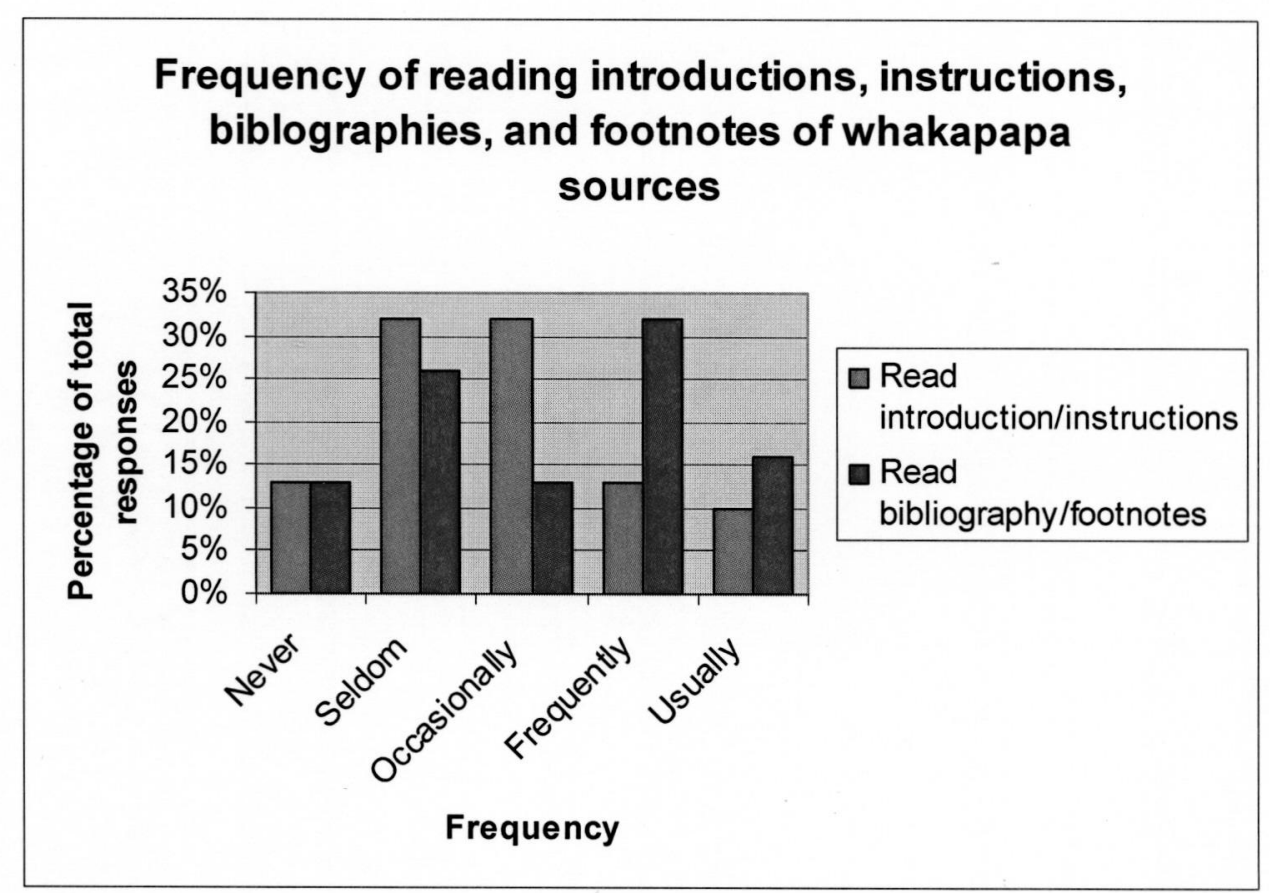




\subsubsection{Librarian produced materials used by whakapapa researchers}

Respondents were asked which kinds of librarian produced materials they had found useful in their whakapapa research (Appendix 2, Question 12). Respondents ticked 115 items (including those written in themselves), resulting in an average of 3.6 items per respondent (Table 4). This is a slightly higher level than the findings in Kuglin's study, though this may be due to additional options being provided for this question in this study. Respondents were given 3 additional options, a guide on the library website about the library's whakapapa sources, a video/DVD about the library's whakapapa sources, and a guided tour of the collection containing whakapapa sources. These options were added as the researcher felt that whakapapa researchers might be making use of information available from library websites. Also Kuglin's study found that $70 \%$ of respondents were interested in watching an introductory video about genealogy sources in the library if one were available and the researcher wondered if this was actually occurring. Finally, guided tours were offered in the public library environment in which the researcher works and this seemed a reasonable addition to the list of options available.

Table 4. Librarian produced materials used by whakapapa researchers

\begin{tabular}{|l|r|}
\hline Materials & Number \\
\hline A printed list of all the sources in the collection arranged by geographic location & 16 \\
\hline A brochure on how to do whakapapa research & 15 \\
\hline A guided tour of the collection containing whakapapa sources & 15 \\
\hline A map showing where whakapapa sources in the library are shelved & 14 \\
\hline A brochure introducing the collection & 13 \\
\hline A guide on the library website about the library's whakapapa sources & 13 \\
\hline $\begin{array}{l}\text { A brochure explaining how the books and microfiche/microfilms are organised on the } \\
\text { shelves }\end{array}$ & 11 \\
\hline A printed list of all the sources in the collection arranged by subject & 8 \\
\hline A video/DVD about the library's whakapapa sources & 7 \\
\hline Other - written in included library catalogue, books that are on display, talking to a librarian & 3 \\
\hline Total number of ticks & $\mathbf{1 1 5}$ \\
\hline
\end{tabular}

Interestingly respondents in this study seem to have a preference for a printed list of sources arranged by geographic location. This may be due to the fact that many 
whakapapa sources are tied closely to tribal rohe/regions and that whakapapa researchers find sources grouped thematically by geography, particularly useful. Guided tours were also ranked quite highly, and this may support the idea that Māori library customers appreciate face to face interaction with librarians while conducting their research. Information on library websites also seem to be well used by whakapapa researchers suggesting that this may be an area that librarians should continue to develop. Very few respondents had found an introductory video or DVD useful to their research but it is not clear whether these are available in many libraries. This could be an area for further study.

\subsubsection{Asking a librarian for help}

Being able to assess the level of independence of library customers, whakapapa researchers in particular, has implications for staffing in public libraries. If particular segments of library users are especially independent, or more reliant on librarian assistance this could have effects on allocations of staff time and staffing levels. For this reason respondents were asked how often per research visit they asked for a librarian's assistance (Appendix 2, Question 13). Again whakapapa researchers seem to be more dependent on librarian assistance than those genealogists surveyed in Kuglin's (2004) study, with 25\% reporting that they asked for assistance more than once per visit (Chart 13). Kuglin's research found that less than $10 \%$ of genealogists made multiple requests per visit and in fact over $60 \%$ of genealogists needed help less than once per visit, indicating that genealogists are reasonably independent researchers. 
Chart 13.

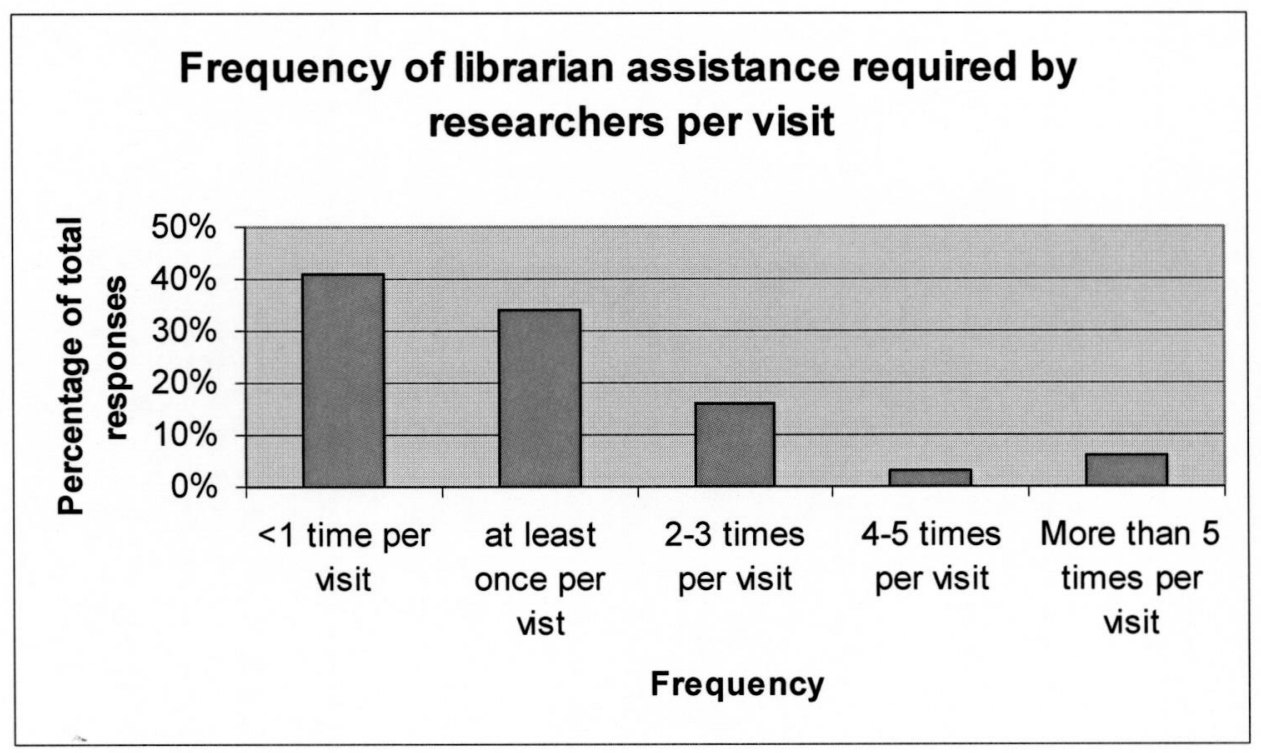

Respondents were also asked what they asked for librarian assistance with

(Appendix 2, Question 14). They were asked to identify 4 reasons that they asked for help but many respondents did not choose 4 options and 2 respondents ticked the "I have never asked a librarian for help" option, in addition to 3 other options. As these answers contradicted themselves these 2 questionnaires were not included in the analysed data for this question (Table 5).

Table 5. Reasons for asking a librarian for help

\begin{tabular}{|l|r|}
\hline Reason & Number \\
\hline To find a source (book, microfilm etc.) that I know the name of & 19 \\
\hline To learn what is in the collection & 15 \\
\hline To find a whānau/family name & 15 \\
\hline To figure out how to use the source I have already found & 10 \\
\hline To learn how to use a genealogy CD-ROM that is in the library computer & 7 \\
\hline To find out how to print something & 6 \\
\hline To learn how to use the library's computer catalogue & 5 \\
\hline To learn how to use the microfiche or microfilm readers & 4 \\
\hline I have never asked a librarian for help & 2 \\
\hline $\begin{array}{l}\text { Other - written in nothing, if I get stuck i.e. printers are different in different systems, } \\
\text { translations }\end{array}$ & 3 \\
\hline Total \# of ticks & $\mathbf{8 6}$ \\
\hline
\end{tabular}

Although in both this and Kuglin's study, finding a source that the respondent already knew the name of was the most often selected option, differences emerge beyond 
this point. Of note is that finding a whānau/family name was the second equal most selected option in this study but was the least often selected option in Kuglin's study. This may be due to the fact that in New Zealand Māori surnames are often less common than European names and are often linked to particular geographical or tribal areas. This also has resonance with the research carried out by Duff \& Johnson (2003) who found that genealogists using archival material would be greatly helped by indexing or finding aids that focused on personal names. Names are clearly an important entry point for whakapapa researchers also. On the whole technical problems to do with the use of machines and other technology did not rank as highly as requests for help in accessing information. Whakapapa researchers are reasonably likely to ask about how to use a source they have already found, with this option coming third. This is not surprising given their underuse of the instructions and introductions of specific sources as discussed earlier (see 5.4.3 Using sources of information effectively).

\subsection{Computer knowledge and experience}

Though many sources of whakapapa information are physically available in public libraries there are also valuable sources of information available in the online environment. Additionally, computers are important conduits or access points to locating information within the library through the use of the library catalogue.

Parker's (2003) research into Māori access and use of information technology suggests that Māori users are subject to a "digital divide", meaning their access to information technologies falls behind that of the general population. This is supported by the work of Duncker (2002) and Simpson (2005) who focused on Māori library customers. Determining whether or not these factors also apply to 
whakapapa researchers will have implications for how public libraries utilise and promote IT (information technology) for these customers.

\subsubsection{General computer experience}

In order to determine what level of computing experience respondents had, they were asked to rate themselves on a scale that allocated different levels of experience according to how long they had been using computers (Appendix 2, Question 15). Although the time spent using computers was not necessarily the most appropriate way of characterising skill levels, this was the scale use in Kuglin's research so for the purposes of comparison this scale was used in this study. No respondents claimed to have no computer experience at all and so all respondents were expected to answer the computing questions that followed. The results in this study were reasonably close to those in Kuglin's earlier research (Chart 14) with the largest percentage of respondents rating themselves as "very experienced". This might suggest that whakapapa researchers have more computing skills than Māori library users generally, possibly as a result of their involvement in whakapapa research. However more research will need to be carried out in order to determine if this is the case. 
Chart 14.

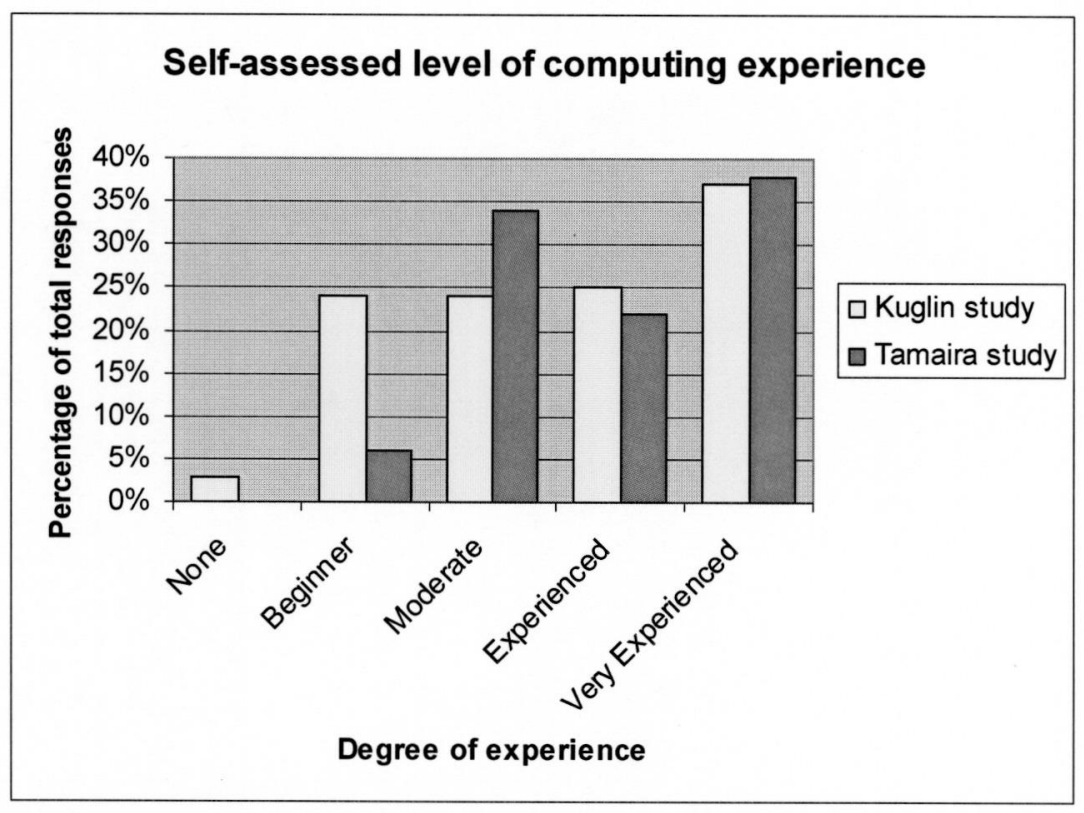

All respondents whose questionnaire was printed from the PDF version made available online rated themselves as "very experienced". Given that these respondents would have to have found the questionnaire online, download it, and print it out, it is not surprising that these respondents would have at least a moderate level of computing experience. Although data from this question was analysed by age, no noticeable trends were evident across the age ranges.

Respondents were also asked in what ways they used computers for whakapapa research (Appendix 2, Question 16). Respondents were given a range of options and these are ranked according to frequency in Table 6 below.

Table 6. Ways of using computers for genealogy

\begin{tabular}{|l|r|}
\hline Different forms of computer use & Number \\
\hline To search genealogy/whakapapa sites on the internet & 25 \\
\hline To search library catalogues & 19 \\
\hline To record research results (i.e. use genealogy software, or word documents) & 18 \\
\hline To use genealogy/whakapapa CD-ROMs & 13 \\
\hline $\begin{array}{l}\text { To communicate with other whakapapa researchers ( via email, letters, newsgroups, or } \\
\text { online forums) }\end{array}$ & 10 \\
\hline $\begin{array}{l}\text { Other - written in included putting photographs of graves online for other researchers, } \\
\text { webmaster of whānau/family webpages }\end{array}$ & 2 \\
\hline Total number of ticks & $\mathbf{8 7}$ \\
\hline
\end{tabular}


In Kuglin's (2004) research the respondents ticked on average 4 options each. In the current research respondents ticked an average of 2.7 options each. This suggests that whakapapa researchers may not be using computers in as diverse a fashion as genealogists in general. In both studies the most often selected option is searching on the internet. Given that Parker's (2003) research found that less than $30 \%$ of Māori had access to the internet at home, the provision of internet access by public libraries may be an important way in which libraries can support their whakapapa researcher customers. Parker also found that $65 \%$ of Māori had never used the internet (Figure 3). This figure is not reflected in the $78 \%$ of respondents in this study for whom searching on the internet was a part of their whakapapa research. This also supports the notion that whakapapa researchers may be more IT savvy than other sections of the Māori population, though more recent statistics than those used by Parker would paint a clearer picture. Further research is needed to identify how heavily whakapapa researchers make use of the computing services on offer at public libraries.

Though at least some respondents are using library websites for this purpose (see 5.4.4 Librarian produced materials used by whakapapa researchers), it is not clear which other internet sites whakapapa researchers use. It is perhaps worth noting that one respondent reported that they were the webmaster of a whānau/family website that contains whakapapa information. The researcher's library and whakapapa research experience suggests that this kind of "homegrown" resource may be a growth area in terms of whakapapa resources online and again, this is an area that could be the subject of future research. 


\subsubsection{Use of the library catalogue}

Respondents were asked how often they used the library catalogue when they were doing whakapapa research at the library (Appendix 2, Question 18). Despite the fact that in Question 16 only 5 respondents stated that they used library catalogues as part of their use of computers in relation to whakapapa research, significantly more respondents reported some use of library catalogues in Question 18 (Chart 15).

\section{Chart 15.}

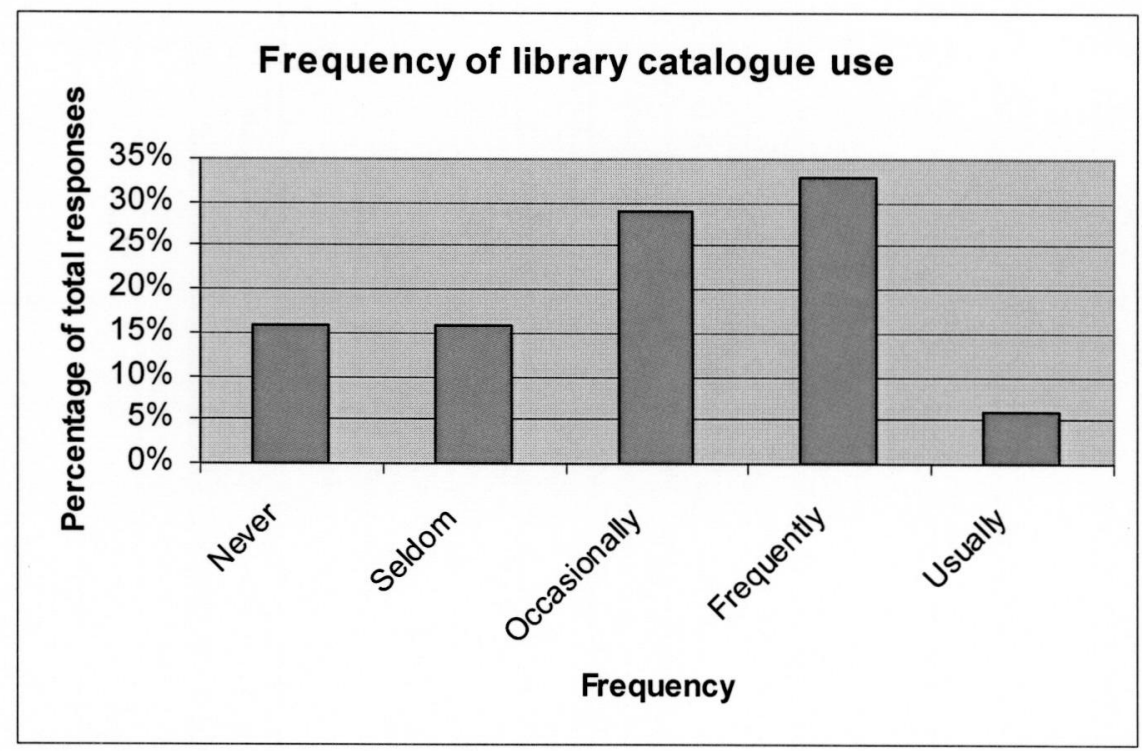

Why this discrepancy should occur is not able to be determined but this was also the case in Kuglin's study. In terms of library catalogue use, perhaps some tool other than a questionnaire may be more useful in accurately recording how often whakapapa researchers or genealogists employ this in their research. In comparing the results from this study with that of Kuglin, catalogue use by whakapapa researchers seems to be higher than that of the genealogists Kuglin surveyed. In Kuglin's study over $50 \%$ of respondents reported that they "never" or "seldom" used the library catalogue. Only $32 \%$ of respondents in this study used the catalogue this infrequently. 
Use of the library catalogue and shelf-browsing were ranked equally highly in terms of usefulness by respondents in question 10. By way of further comparison respondents were asked in different questions how often they found information useful to their research by browsing the shelves or searching the library catalogue (Appendix 2, Question $17 \& 19$ ). Again, respondents perceived that they had similar levels of success with shelf-browsing as with catalogue searching (Chart 16).

\section{Chart 16.}

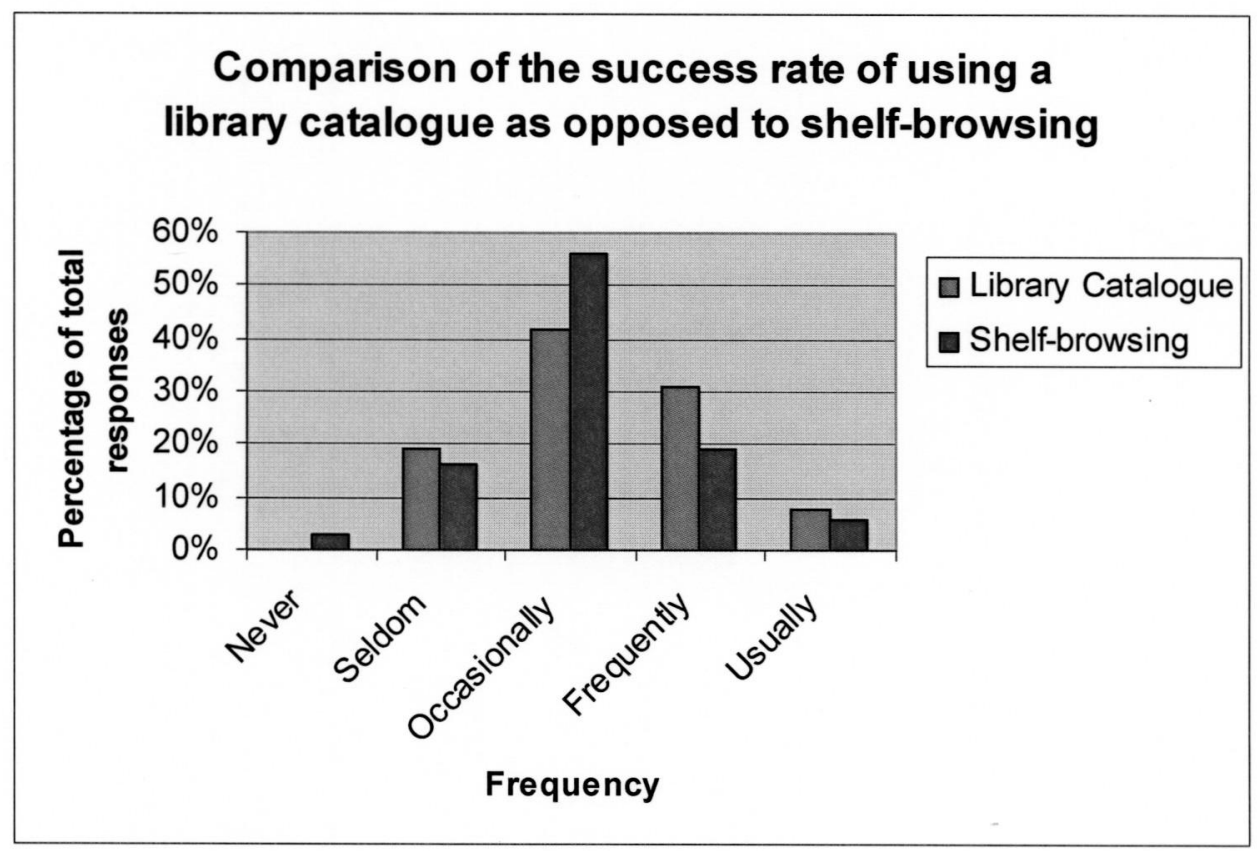

The results from these questions differ noticeabley when compared with Kuglin's research. Kuglin found that $58 \%$ of respondents "frequently" or "usually" found useful information by shelf-browsing whereas this study has only $25 \%$ doing so. Also Kuglin's data has $31 \%$ of respondents "frequently" or "usually" successfully finding information by using the computer catalogue whereas $39 \%$ of respondents in this study claimed that this strategy was "frequently" or "usually" successful. Overall, Kuglin's study shows shelf-browsing as the more successful search strategy where this study shows whakapapa researchers enjoy similar degrees of success with both 
strategies. There is no way of determining in the current research if this is because whakapapa researchers are better at shelf-browsing, or are not as good at catalogue searching, or if some other factor is at play. The relative success rates of shelfbrowsing and catalogue searching clearly requires further investigation.

Respondents who "never" or "rarely" used a library catalogue were then asked what reasons they had for not utilising this tool. 12 respondents answered this question (Appendix 2, Question 20) despite the fact that only half of these had previously reported that they used the catalogue "never" or "seldom". Due to the small number of respondents who "legitimately" answered the question as requested, it was decided by the researcher to allow all ticks to be included in the analysed data (Chart 17).

\section{Chart 17.}

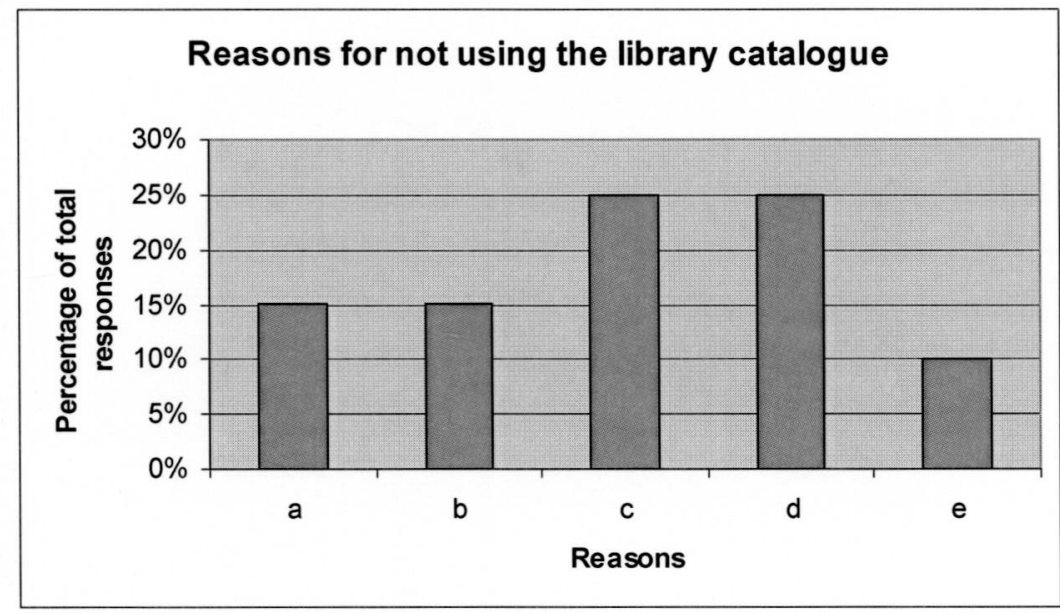

\section{Legend}

a. I can't figure out how to use it

b. I don't know what words to use to do my search

c. I can never find what I want

d. I prefer to browse the shelves

e. The catalogue doesn't

"understand" Māori words.

Due to the small numbers responding to this question it is difficult to know if any conclusions can be drawn from the data, though in Kuglin's study option d "I prefer to browse the shelves" was overwhelmingly the most reported reason with over $50 \%$ of respondents ticking this option. In this study the reasons are less clear but there is certainly some frustration in using library catalogues even by researchers who use them frequently. Of the 2 respondents who wrote in their own answers, one simply 
stated that they didn't like it, while the other described in detail how the libray's software had been upgraded and felt that staff support in adjusting to the new system was lacking. If used effectively library catalogues can offer a certain level of independence to researchers. Whakapapa researchers may well benefit from gaining some familiarity with library catalogues either by one on one tuition fom librarians or in a group. 


\section{Conclusions and recommendations}

\subsection{Summary of the data}

This study aimed to capture information about whakapapa researchers based in different parts of New Zealand but in actuality most of the data was gathered from North Island based researchers. It was also hoped that enough data would be gathered that trends and patterns in use could be determined. Due to the comparatively small number of questionnaires returned, this has been possible in some, but not all instances.

In terms of gender the analysed data from this study tends to reflect the data from earlier studies on genealogists both in North America, by those such as Drake (2001) and Lambert (1998), and New Zealand by Kuglin (2004) in confirming that genealogists, and in this case whakapapa researchers are predominantly female. However there are definite differences in terms of the age of whakapapa researchers with this study showing that they are younger than genealogists in the general population. This may be partly due to Mãori being younger generally in the population, having an average life expectancy 7.6 years shorter than that of the total population $^{6}$ or it may be that whakapapa research is of a broader interest in the Māori population than it is generally. Possibly it is a combination of these and other unknown factors.

This study confirmed that though the majority of whakapapa researchers have Māori ancestry, there is a minority of researchers who have no Māori ancestry themselves. Due to the relatively low number of completed questionnaires, it is not possible to

\footnotetext{
${ }^{6}$ Statistics New Zealand (2005)
} 
state whether the percentage of researchers who fit into this category would remain at $9 \%$ in a larger sample.

Whakapapa researchers share with New Zealand genealogists generally and North American counterparts a desire to gain a sense of identity or rootedness through their research. Whakapapa researchers, like other genealogists, are also concerned with preserving this information for their descendants and other family members. Litzer (1997) posits the theory that genealogy as a hobby is increasing due to the third generation principle, wherein first and second generation immigrants, such as those in the United States, seek to assimilate themselves within the dominant culture distancing themselves from their roots. In turn a reconnection with these same roots is then sought by the third generation. Kuglin (2004) considers that this principle plays into the genealogical interest of New Zealanders with immigrant backgrounds however, as the indigenous culture, Māori can not be said to be affected by such a motivation. What may factor into Māori interest in whakapapa or genealogy though, is a loss of connectedness with their iwi/tribal roots. Up until the mid twentieth century Māori had lived mainly in rural areas with a strong connection to their tribal roots. Post World War II a dramatic shift occured with large numbers of Māori leaving these rural areas in search of employment in New Zealand's urban centres. The social changes brought about by this rural-urban shift are discussed in more detail by Barcham (1998) but it is possible that this dis-connectedness may account for an interest in whakapapa and/or for some whakapapa researchers' reliance on public library sources of information as opposed to traditional sources such as kaumatua/tribal elders. 
help them with their research, though they may not be using these sources as effectively as those in Kuglin's study. For most whakapapa researchers reading the introduction or instructions of a source is an infrequent activity. Though respondents reported that they used bibliographies and footnotes more frequently, better skills in this area might increase researcher independence.

Whakapapa researchers are reasonably high users of librarian produced materials/finding aids and have a preference for printed lists that group sources geographically rather than by subject. They also utilise introductory brochures on how to conduct whakapapa research, and the whakapapa sources in the collection. The respondents in this study did not limit themselves to only printed materials though as they also take advantage of guided tours of whakapapa resources in the library and consult with online guides on library websites. In addition to these librarian produced resources, librarians themselves are of particular use to whakapapa researchers who are more likely than the respondents in Kuglin's (2004) study to ask for librarian assistance while visiting the library. When these researchers ask for help it is more likely to be in the context of needing assistance accessing information than with needing help with a piece of technology.

Technology, specifically computers, features in the whakapapa research of respondents in this study with them reporting a similar level of computer experience as those in Kuglin's (2004) research. Despite research by Parker (2003) that suggests Māori have less experience with and access to IT, this was for the most part not reflected in the level of self-assessed computer experience that whakapapa researchers reported. However their may be some gap in that respondents in 
Kuglin's study reported more variation in the ways they used computers in genealogy research than was the case with the respondents in this study. Use of library computer catalogues however seemed to be more popular with the respondents in this study than in Kuglin's.

In Kuglin's (2004) study there was a definite preference, and better perceived success rate in shelf-browsing over use of the library catalogue. In this study the difference between the use of these two information seeking strategies was much less pronounced. As a resource, the library catalogue was ranked as the second most useful after asking a librarian. The reasons that respondents had for not using the catalogue were less obvious though, than in Kuglin's research, though clearly there is some difficulty in using this resource for some whakapapa researchers.

In summary, this piece of research has determined that whakapapa researchers are younger than genealogists previously studied, with most under, rather than over, retirement age. They are predominantly female but to a lesser extent than has been found in other studies on genealogists, and they become involved in their research to more fully develop their sense of identity. Whakapapa researchers are somewhat less experienced in their genealogical research than other genealogists but make use of a variety of institutions and resources in their research. Some of the sources that they most frequently consult specifically contain Māori information but others contain family history information useful to other kinds of genealogists. They are not particularly independent users of public libraries and often ask for librarian assistance, particularly in order to access information. On initial visits to unfamiliar public libraries they are most likely to seek out the Māori reference librarian for help 
than by using any other strategy. They are reasonably experienced users of computers, often searching for whakapapa information online and they find the library catalogue as useful as shelf-browsing in finding the information they need.

\subsection{Recommendations}

Historically, Māori have had a difficult relationship with public libraries and libraries in general. Finding ways to support whakapapa research is one way in which public libraries can help to make themselves a more attractive option for this growing section of New Zealand society. In addition, providing services and tools that educate whakapapa researchers in their use of the public library may increase the level of independence that these researchers have.

- Public libraries should consider offering workshops, seminars and/or guided tours specifically devoted to the whakapapa sources held in the library. Basic information about how to use these whakapapa sources should be included in order to give researchers a good grounding and familiarity with these resources.

- Whakapapa researchers are much more inclined to ask a librarian for help than use other resources. They are also more dependent on librarian assistance than other genealogists so where possible a Māori reference librarian should be available in the vicinity of the main whakapapa resources will mean that these library customers get the help that they need. 
- If there are not already printed resources specifically aimed at whakapapa researchers, such as an introductory guide to research, or lists of whakapapa sources listed by region, then these should be produced.

- Ensure that staff who deal with genealogical resources such as births, deaths, and marriages indexed and electoral rolls, which for the most part will not form part of a Māori collection, have sufficient training and understanding of these resources to be able to assist a whakapapa researcher in their use.

- Look to acquire copies of Māori Land Court/Te Kooti Whenua Māori records if these are not already owned. Ensure that appropriate indexes for this information are also available.

- Investigate what whakapapa sources are available online and make these accessible via the library website. Create or maintain a guide to the library's whakapapa sources on the library website.

\subsection{Further research}

While this study has sought to investigate the public library use of whakapapa researchers and has looked at various aspects such as the library resources they use and the search strategies they employ, there are many more areas of this topic that could be the subject of further study.

- Although the use of computers in relation to whakapapa research has been discussed here, further study could look at the degree to which public libraries 
supply access to IT for whakapapa researchers. Do whakapapa researchers have internet access elsewhere that they use or are public libraries the sole source of internet access? Regarding the internet, what is the attitude of whakapapa researchers, given that whakapapa is considered tapu/sacred in traditional Māori culture, to this information being available online? Does this have implications for digital library collections?

- This study focused largely on urban-based whakapapa researchers, but there may be differences between the information seeking behaviours of urban whakapapa researchers and those based in rural areas.

- Further study could also investigate the cultural significance of whakapapa and how this may affect how libraries, public or otherwise, provide services to these patrons. How do whakapapa researchers feel about how whakapapa information is treated by libraries and archives? Are the levels of access to information that may be considered sacred by Māori, appropriate? Is the physical environment of the library suitable to the needs of these researchers?

- This study achieved a comparatively low response rate of returned questionnaires. Future research could employ alternate forms of data gathering such as interviews. Ideally researchers involved in interviews with whakapapa researchers would best be based in the North Island so as to have access to a larger pool of Māori population. Alternately investigation of whakapapa researchers' interactions with tools such as the library catalogue 
could benefit from utilising observed behaviour or "experiment-conversations" like those used by Duncker (2002).

- Future research could also investigate whakapapa research in other library or archives environments. University libraries often hold significant whakapapa resources and the use of archival material has not really been covered here. Future research might also look at the role of tribally based repositories in whakapapa research such as marae-based libraries and the whakapapa units/libraries of tribal organisations. 


\title{
Appendices
}

\section{Appendix 1. Letter of Information}

\author{
VICTORIA UNIVERSITY OF WELLINGTON \\ Te Whare Wänanga o te Üpoko o te Ika a Mäui

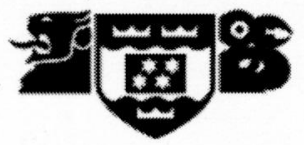

SCHOOL OF INFORMATION MANAGEMENT

Ko Te Arawa te waka

Ko Ngāti Tuwharetoa te iwi

Ko Moata Tamaira tōku ingoa

Tēnā koe,

My name is Moata Tamaira and I am a student with the Masters of Library and Information Studies programme at Victoria University of Wellington. I am undertaking a research project as part of this course that will investigate how customers in public libraries go about researching whakapapa, Māori genealogy. The aim of my research is to be able to identify ways in which public library services to whakapapa researchers might be improved. XXX Library has kindly given permission for me to distribute this questionnaire to customers who use the library for whakapapa research. Your participation in this study would be greatly appreciated.

Participation in this study is completely voluntary. Your contribution will be totally anonymous and I will not be able to identify who filled in which form. You will not be asked to supply any information that could identify you and I ask that you do not include your name anywhere on the questionnaire form. Your informed consent to this survey is implied by your voluntary participation. Ethical approval to carry out this research project has been granted by the School of Information Management Human Ethics Committee, Victoria University of Wellington.

Your completed survey, once received will be kept by me in a secure, locked drawer. Only myself and my supervisor, Alastair Smith will see the completed questionnaires and once this research project is completed and the final report written and approved, all survey forms will be destroyed.

If you use public libraries to do whakapapa research then please fill in the attached survey. You do not need to have Māori ancestry yourself but must be involved in researching Māori genealogy or family history. I estimate it should take approximately $10-15$ minutes to fill in. Please answer all questions as accurately as possible and do not include your name anywhere on the form. When you have completed the survey please put it in the box provided or if you would like to take it with you to fill in later please take one of the self-addressed freepost envelopes. Please do not include a return address on the envelope when you send it. The cut-off date for receiving surveys back will be 31 August 2007.

A copy of the completed research report will be deposited with the Victoria University of Wellington library and will be available on the internet at 
http://www.searching4tupuna.blogspot.com . The results may also be published in academic, professional, or genealogical journals or presented at professional conferences. At the conclusion of the project participating libraries will also be given aggregated data as relates to users of their library. This will not take a form that may identify any individual participant.

If you have any questions about this research project or wish to be sent a copy of results please contact me or my supervisor at;

\section{Moata Tamaira}

Flat 1 - 198 Bealey Avenue

Christchurch

Telephone: (03) 941-5962 or 021-625-525

E-mail: moata.tamaira@ccc.govt.nz

\author{
Alastair Smith \\ School of Information Management \\ Victoria University of Wellington \\ PO Box 600 \\ Wellington \\ E-mail: alastair.smith@,vuw.ac.nz
}

Kia ora. 


\section{Appendix 2. Survey Questionnaire}

\section{Survey Questionnaire}

\section{Whakapapa Research Experience and Interest}

1. How did your interest in whakapapa research begin? (tick any boxes that apply)
a. for posterity (to keep a record for future generations)
b. to learn about my roots, about who I am.
c. to carry on work already begun by another family/whānau member(s).
d. to keep my whakapapa researcher wife/husband/partner company.
$\square \quad$ e. to trace medical conditions in a family tree
f. for religious/spiritual reasons.
g. for employment (as a paid researcher).
$\mathrm{h}$. to meet living relatives.
i. because I enjoy the company of other whakapapa researchers/genealogists.
j. I had to provide whakapapa to qualify for an education grant/scholarship.
k. I had to provide whakapapa to register with my iwi.
l. Other reason. Please state.

2. How long have you been researching whakapapa? (tick one box that best describes you)
$\square \quad$ a. less than 1 year.
b. 1-2 years.
c. 3-4 years.
d. 5-10 years.
e. more than 10 years

3. How much time on average do you spend doing whakapapa research? (tick the one box that best describes you.)
a. less than an hour a month (less than 12 hours a year)
b. 1-3 hours a month
c. 4-15 hours a month (about 1-3 hours per week)
d. 16-25 hours a month (about 4-6 hours per week)
e. 26-40 hours a month (about 7-10 hours per week)
f. 41-60 hours a month (about 11-15 hours per week)
g. over 60 hours a month (more than 15 hours per week

4. While the rest of this questionnaire relates specifically to your whakapapa research in public libraries, this question asks about which libraries, archives, museums and iwi rūnanga you have visited to do whakapapa research. (Tick any that apply.)
a. Local public library
b. Public library in another city or town. 

c. National Library of New Zealand/Alexander Turnbull Library
d. Archives New Zealand (National Archives)
e. Local museum or museum library.
f. Museum or museum library in another city or town
g. Marae-based library
h. Genealogical society library
i. Latter Day Saints (Mormon) Family History Centre
j. Iwi rūnanga whakapapa unit/office
k. Other: Please state. -

5. How often on average do you go to a public library to do whakapapa research? (Tick one box that best describes you.)
$\square \quad$ a. 2-3 times a week.
b. once a week.
c. 2-3 times a month.
d. once a month.
e. every 3-4 months.
f. twice a year.
g. once a year or less.

6. How much time on average do you spend per visit to the library to do whakapapa research? (tick the one box that best describes you.)
$\square \quad$ a. less than 1 hour
b. 1 hour
c. 2-3 hours
d. 4-5 hours
e. more than 5 hours

Finding the information you need in the library.

7. If you were to visit a new library that you are unfamiliar with to do whakapapa research what is the first thing you would do? (Tick the one box that applies.)
a. consult the genealogy reference librarian
b. consult the Māori reference librarian
c. search the library catalogue
d. browse the genealogy shelves
e. browse the Mãori collection shelves
f. look for a brochure or other printed guide to introduce me to the collection.
g. use the online whakapapa sources.
h. Other: Please state.

8. If you were to visit this same library (as in question 7) again what is the first thing you would do?
a. consult the genealogy reference librarian
b. consult the Māori reference librarian
c. search the library catalogue
d. browse the genealogy shelves 

e. browse the Māori collection shelves
f. look for a brochure or other printed guide to introduce me to the collection.
g. use the online whakapapa sources.
h. Other: Please state.

9. Which of the following sources do you use when researching whakapapa in a public library? (Please tick any that apply)

\begin{tabular}{lll}
\hline & a. & Births, deaths, marriages index \\
$\square$ & b. Electoral rolls \\
$\square$ & c. Census records \\
$\square$ & d. Cemetery/Urupa records \\
$\square$ & e. Church records \\
$\square$ & f. Māori Land Court/Te Kooti Whenua Māori records \\
$\square$ & g. Other land records \\
$\square$ & h. Military records \\
$\square$ & i. Telephone/postal directories \\
$\square$ & j. Published genealogies or family histories \\
$\square$ & k. Waitangi Tribunal reports or evidence \\
$\square$ & I. Other: Please state.
\end{tabular}

10. How do you most frequently find a whakapapa source that is useful to your research? (Rank the following in the order of frequency, 1 being the most frequent and 6 being the least frequent).

a. by checking the computer catalogue

b. by browsing the shelves

c. by reading a printed brochure or guide

d. by asking the librarian

e. by consulting a fiche or CD-ROM index

f. Other: Please state.

11. When you find a source that you can use, how often do you:

you.)

a. read the introduction and instructions. (Tick one box that best describes
a. Never
b. Seldom (about 1 time in 10)
c. Occasionally (about 3-4 times in 10)
d. Frequently (about 5-6 times in 10)
e. Usually (about 7-10 times in 10)

b. read the bibliography or footnotes to find other sources. (Tick one box that best describes you.)
a. Never
b. Seldom (about 1 time in 10)
c. Occasionally (about 3-4 times in 10)
d. Frequently (about 5-6 times in 10)
e. Usually (about 7-10 times in 10) 


\section{Librarian provided assistance}

12. Which of the following have you used to help you do your whakapapa research? (Tick any that you have found useful.)
$\square \quad$ a. A brochure introducing the collection.
$\square \quad$ b. A brochure explaining how the books and microfiche/microfilms are organised on the shelves.
c. A map showing where whakapapa resources in the library are shelved.
$\square \quad$ d. A printed list of all the sources in the collection arranged by subject. (eg. Land sources, Church sources )
$\square \quad$ e. A printed list of all the sources in the collection arranged by geographic location. (eg. Northland/Tai Tokerau, Canterbury/Waitaha)
$\square \quad$ f. A brochure on how to do whakapapa research.
$\square \quad$ g. A guide on the library website about the library's whakapapa sources.
$\square \quad$ h. A video/DVD about the library's whakapapa sources.
$\square \quad$ i. A guided tour of the collection containing whakapapa sources.
$\square$ j. Other: Please state.

13. How often on average do you ask a librarian for help with your whakapapa research in a given library visit? (Tick one box that best describes you.)
a. less than once a visit
b. at least once a visit
c. 2-3 times a visit
d. 4-5 times a visit
e. More than 5 times a visit

14. What have you asked a librarian for help with? (Tick the four most frequent reasons.)
$\square \quad$ a. to find a family/whanau name
$\square \quad$ b. to find a source (book, microfilm, etc.) that I know the name of.
$\square \quad$ c. to learn what is in the collection
$\square \quad$ d. to figure out how to use the source I have already found.
$\square \quad$ e. to learn how to use the library's computer catalogue.
$\square$ f. to learn how to use a genealogy CD-ROM that is in the library computer.
$\square \quad$ g. to learn how to use the microfiche or microfilm readers.
h. to find out how to print something out.
$\square \quad$ i. I have never asked a librarian for help.
$\square$ j. Other: Please state. 


\section{Computer Knowledge and Experience}

15. How do you rate your experience as a general computer user? (Tick the one box which best describes you)
a. No experience (Go to question 21)
b. Beginner (less than a year)
c. Moderately experienced (1-2 years)
d. Experienced (3-4 years)
e. Very experienced (5+ years)
f. your comment:

16. In what ways do you use a computer for your whakapapa research? (Tick any that apply)

$\square \quad$ a. to record research results (i.e. use genealogy software, or word documents)

b. to search genealogy/whakapapa sites on the internet.

c. to search library catalogues.

d. to use genealogy/whakapapa CD-ROMs

e. to communicate with other whakapapa researchers (via email, letters, newsgroups, or online forums)

f. Please state any other ways.

17. On average, how often do you find information useful to your research by browsing the shelves? (Tick one box that best describes your success rate.)
a. Never
b. Seldom (about 1 time in 10)
c. Occasionally (about 3-4 times in 10)
d. Frequently (about 5-6 times in 10)
e. Usually (about 7-10 times in 10)

18. How often do you use the library's computer catalogue when you are looking for whakapapa resources at the library? (Tick the one box that best describes you.)
a. Never (Go to question 20)
b. Seldom (about 1 time in 10)
c. Occasionally (about 3-4 times in 10)
d. Frequently (about 5-6 times in 10)
e. Usually (about 7-10 times in 10)

19. On average, how often do you find information useful to your research using a library catalogue? (Tick one box that best describes your success rate.)
a. Never
b. Seldom (about 1 time in 10)
c. Occasionally (about 3-4 times in 10)
d. Frequently (about 5-6 times in 10)
e. Usually (about 7-10 times in 10) 
20. If you never or rarely use the library catalogue, which of these reasons describes why not. (Tick any of the boxes that apply) (Frequent catalogue users go to question 21)
a. I can't figure out how to use it
b. I don't know what words to use to do my search
c. I can never find what I want
d. I prefer to browse the shelves
e. The catalogue doesn't "understand" Māori words
f. Other: Please say why you don't use the library catalogue

\section{General information about you}
21. Gender:
$\square$ Female
$\square$ Male

22. In what age group are you? (Tick one box)

$\begin{array}{llrl}\square 20 \text { or under } & \square 21-30 & \square 31-40 & \square 41-50 \\ \square 51-60 & \square 61-70 & \square \text { Over } 70 & \end{array}$

23. Do you have any Māori ancestors/tūpuna yourself?
$\square$ yes
$\square$ no
$\square$ not sure

24. When doing whakapapa research, whose ancestors do you research? (tick any that apply)
a. my own
b. my spouse/partner's
c. my friend's
d. my children's
e. my grandchildren's
f. those of other genealogists/whakapapa researchers
g. those of a client, as a paid researcher

25. Before you started doing whakapapa research, how often on average did you use a library? (Tick the one box that best describes you.)
$\square \quad$ a. 2-3 times a week or more.
$\square \quad$ b. At least once a week.
c. 2-3 times a month.
d. Once a month.
e. Every 3-4 months.
f. Twice a year.
g. Once a year or less.

26. Before starting whakapapa research did you have any experience doing research in a library that resulted in writing an article or a report?
a. Yes
b. No

27. Which public library do you use most often do to whakapapa research? 
Appendix 3. Aggregate data for Question 10

\begin{tabular}{|c|c|c|c|c|c|c|}
\hline \multirow[b]{2}{*}{ Options } & \multicolumn{6}{|c|}{ Rankings, 1-6 } \\
\hline & 1 & 2 & 3 & 4 & 5 & 6 \\
\hline a. By checking the computer catalogue & 5 & 9 & 5 & 4 & 2 & 0 \\
\hline b. By browsing the shelves & 4 & 11 & 3 & 5 & 2 & 0 \\
\hline c. By reading a printed brochure or guide & 2 & 2 & 7 & 4 & 8 & 2 \\
\hline d. By asking the librarian & 11 & 1 & 5 & 6 & 2 & 0 \\
\hline e. By consulting a fiche or CD-ROM index & 2 & 2 & 4 & 5 & 10 & 2 \\
\hline f. Other (not stated) & 0 & 0 & 1 & 0 & 0 & 18 \\
\hline \multicolumn{7}{|l|}{ Items written in by respondents } \\
\hline Computer databases & 0 & 0 & 0 & 0 & 1 & 0 \\
\hline Aotearoa room & 1 & 0 & 0 & 0 & 0 & 0 \\
\hline Whanau/hapu iwi & 0 & 0 & 0 & 0 & 0 & 1 \\
\hline Evaluate next step to take, note taking etc. & 0 & 0 & 0 & 1 & 0 & 0 \\
\hline
\end{tabular}




\section{Bibliography}

Australian Bureau of Statistics (2006) 2001 Census of Population and Housing:

Ancestry by birthplace of parents, Retrieved on 16 March 2007 from

http://www8.abs.gov.au/ABSNavigation/download?format=xls\&productlabel=Ancestry

by Birthplace of Parents\&producttype=census tabl

Barcham, M. (1998) The challenge of urban Māori: reconciling conceptions of indigeneity and social change. Asia Pacific Viewpoint, 39 (3), (pp.303-314).

Retrieved 22 September 2007 from Blackwell Humanities \& Social Sciences Collection

Biggs, B. (2001) Library of California Tierra del Sol region tribal library census and needs assessment project final report, Retrieved on 25 August 2007 from http://www.csusm.edu/bbiggs/loc/report.html

Cresswell, J. (2003) Research Design: Qualitative, Quantitative, and Mixed Methods Approaches, Thousand Oaks, Calif. : Sage Publications.

Drake, P. J. (2001). Findings from the Fullerton Genealogy Study - a master's thesis project. Retrieved 2 August 2006 from http://psych.fullerton.edu/genealogy/

Duff, W. M. and Johnson, C. A. (2003) Where is the list with all the names? Information-seeking behavior of genealogists. American Archivist, 66(1), (pp. 79-95) 
Duncker, E. (2002) Cross-cultural usability of the library metaphor. Proceedings of the 2nd ACM/IEEE-CS joint conference on Digital libraries, (pp. 223-230) Retrieved on 2 September from The ACM Digital Library

Hemara, W. (2005) Whakapapa : as curricula \& pedagogical practice : an historical, social \& philosophical discourse on Māori engagement with traditional \& contemporary education : a thesis submitted to the Victoria University of Wellington in fulfilment of the requirements for the degree of Doctor of Philosophy in Education.

Ikoja-Odongo R. and Ocholla D. N. (2004) Information seeking behaviour of the informal sector entrepreneurs: The Uganda experience. Libri: International journal of libraries and information services, vol. 54, iss. 1. Retrieved on 27 August 2007 from Ebscohost

Joyce, B. (2007) RE:Researching whakapapa researchers. Personal communication (e-mail message) on 11 January 2007.

Kuglin, H. (2004). Granny hunting: the information seeking behaviour of genealogists in open access libraries : submitted to the School of Information Management, Victoria University of Wellington in partial fulfilment of the requirements for the degree of Master of Library and Information Studies. Wellington, Victoria University of Wellington. May 2004.

Lambert, R. D. (1998) Roving reporters: a study of genealogists and family historians, Pt. 1. The Global gazette : Canada's online family history magazine, vol. 
2, no. 17. Retrieved on 14 January 2007 from

http://globalgenealogy.com/globalgazette/gazrr/gazrr19.htm

Lambert, R. D. (1999) Roving reporters: a study of genealogists and family

historians, Pt. 2. The Global gazette : Canada's online family history magazine, vol.

2, no. 17. Retrieved on 14 January 2007 from

http://globalgenealogy.com/globalgazette/gazrr/gazrr20.htm

Latham, B. M. (2003). The genealogist and the library: an interesting partnership. Alabama Librarian, vol. 53, no. 1 Retrieved 25 August 2007 from WilsonWeb

Litzer, D. S. (1997). Library and genealogical society cooperation in developing local genealogical services and collections. Reference \& user services quarterly, vol. 37, no. 1 Retrieved 31 July 2006 from ProQuest.

McDonald, T. (1993). Te ara tika : Māori and libraries : a research report. Wellington [N.Z.] : New Zealand Library \& Information Association.

Parker, B. (2003). Maori access to information technology. The Electronic Library, vol. 21, no. 5 (pp. 456-460), Retrieved 8 August 2006 from Emerald.

Royal, T. C. (1992) Te Haurapa: an introduction to researching tribal histories and traditions. Wellington: Bridget William Books. 
Simpson, S. (2005) Te ara tika: guiding words: Nga ingoa kaupapa Māori, pūrongo tuatoru: Māori subject headings project, phase 3 research report, Retrieved on 27 July 2007 from http://www.trw.org.nz/publications/Te Ara_Tika_Guiding Words.pdf

Sinko, P. and Peters, S. (1983). A survey of genealogists at the Newberry Library. Library Trends, no. 32 (pp. 97-109).

Statistics New Zealand (2001) Brochure Dunedin City Census 2001 area data.

Retrieved on 20 September 2007 from

http://www2.stats.govt.nz/domino/external/pasfull/pasfull.nsf/web/Brochure+Dunedin + City+Census+2001+Area+data?open

Statistics New Zealand (2001) Brochure Manukau City Census 2001 area data.

Retrieved on 20 September 2007 from

http://www2.stats.govt.nz/domino/external/pasfull/pasfull.nsf/web/Brochure+Manukau + City+Census $+2001+$ Area+data?open

Statistics New Zealand (2002) 2001

Census of population and dwellings : Ethnic Groups, Retrieved 9 October from http://www.stats.govt.nz/NR/rdonlyres/988C1E07-45FD-4A14-8164393B5CFDF513/0/EthnicGroups01.pdf

Statistics New Zealand (2005) Demographic Trends, Retrieved 9 October from http://www.stats.govt.nz/NR/rdonlyres/901D40E4-9607-4215-807F9C22CDC98618/0/DemographicTrends20052.pdf 
Szekely, C. (1992) Māori people in libraries. Sites, no. 25, Summer 1992, (pp. 63-68)

Szekely, C. (1997) Te ara tika : guiding voices : Māori opinion on libraries and information needs. Wellington [N.Z.] : New Zealand Library \& Information Association ; Te Rōpū Whakahau

Ta'ala, T. M. (2006) No wai koe? Whakapapa, records and the role of iwi runanga in defining Maori identity : submitted to the School of Information Management, Victoria University of Wellington in partial fulfilment of the requirements for the degree of Master of Library and Information Studies.

Worth, H. (1995) The customer's voice - a quest : a survey : improvement of services to Maori at Auckland City Libraries. Auckland, N.Z. : Auckland City Libraries.

Yakel, E. (2004). Seeking information, seeking connections, seeking meaning:

genealogists and family historians. Information Research, vol. 10, no. 1, Retrieved 31 July 2006 from http://informationr.net/ir/10-1/paper205.html 